\title{
The Impact of Organizational Structure and Business Strategy on Performance and Risk-Taking Behavior in Insurance Industry
}

\author{
Gene C. Lai ${ }^{1}$, Lin-Yhi Chou ${ }^{2} \&$ Lih Ru Chen ${ }^{3}$ \\ ${ }^{1}$ Gene C. Lai is the Safeco Distinguished Professor of Insurance and the department chair of the Department of Finance \\ and Management Science, Washington State University. \\ ${ }^{2}$ Lin-Yhi Chou is at the Department of Risk Management and Insurance, Shih Chien University, Taipei, Taiwan. \\ ${ }^{3}$ Lih Ru Chen is at the Department of Risk Management and Insurance, Shih Chien University, Taipei, Taiwan. \\ Corresponding: Lih Ru Chen, Department of Risk Management and Insurance, Shih Chien University, Taipei, Taiwan \\ (R.O.C.)
}

Received: November 12, 2014

Accepted: November 27, 2014

Available online: July 22, 2015

doi:10.11114/afa.v1i2.911

URL: http://dx.doi.org/10.11114/afa.v1i2.911

\begin{abstract}
This paper examines the impact of organizational structure and business strategy on company efficiency, profitability, and risk-taking behavior in the Taiwanese life insurance industry. The insurance industry in Taiwan provides an interesting environment for studying this issue because different organizational forms coexist in the insurance industry. We examine four different types of companies by organizational structure and two different business strategies. We use two frontier methodologies (stochastic frontier approach and data envelopment analysis approach) to measure the efficiency performance of insurance firms. The results show that organizational structures and business strategies have significant impact on efficiency, profitability, and risk-taking behavior. In addition, we also find size, lines of business, leverage ratio, and market share have significant impact on efficiency, profitability, and risk-taking behavior. Our overall evidence suggests that a more competitive environment should be encouraged in the Taiwanese insurance industry to improve the insurer efficiency.
\end{abstract}

Keywords: Efficiency; Profitability; Risk-Taking Behavior; Organizational Structure; Business Strategy

\section{Introduction}

The relation between organizational structure and performance has been an important topic in the insurance industry. Two types of performance have been examined, namely, efficiency and profitability. For example, Cummins, Weiss, and $\mathrm{Zi}$ (1999) examine the efficiency of different organizational form in U.S. property-liability insurance industry. Lai and Limpaphayom (2003) investigate the impact of organizational structure on firm performance using profitability as a performance measure in the Japanese non-life insurance industry. While most recent literature finds, in general, the insurance company with lowest operation cost will increase its profit, Berger and Mester (1997) show that profit efficiency is not positively correlated with cost efficiency. Therefore, we believe that it is important to examine both performance measures together.

The relation of organizational structure and risk taking has been examined in the literature. For example, Lamm-Tennant and Starks (1993) provide evidence of the risk differences between different types of ownership structure. They, however, have not investigated the relation between risk taking and profitability simultaneously. We believe it is critical to examine risk-taking behavior and profitability simultaneously because risk and return are trade-offs.

Business strategy is known to have impact on the efficiency and profitability. For example, Meador, Ryan and Schellhorn (2000) find the X-efficiency increases with product diversification for the U.S. life insurance industry. Jeng and Lai (2005) report the keiretsu insurance companies are more cost efficient than non-specialized independent firms in Japan. Regarding profitability, Liebeskind and Opler (1993) and Comment and Jarrell (1995) find a positive relation between return and specialization.

The issue of whether a firm's business strategy (diversification or focus strategy) has impact on its risk has been at the center of a large body of literature in corporate finance. The conventional opinion is that product diversification reduce 
a firm's exposure to a specific risk from providing particular product, thus, reduce its risk; whereas an alternative view is that expansion into new nontraditional activities may result in unstable income and greater risk (e.g., Berger, Cummins, Weiss, and Zi, 2000; Esho, Kofman, and Sharpe, 2005). Empirically, the prior studies produced mixed results (e.g., Brewer, 1989; Hassan et al., 1994; Esho et al., 2005). Berger et al. (2000) found that profit scope economies variable is positively related to risk, consistent with the conventional view. Their sample includes both life and P-L insurance industries.

The purpose of this paper is to examine the impact of organizational structure and business strategy on performance and risk-taking behavior. Our sample includes 26 Taiwan's life insurance companies during the period from 1977 to 2002 . To the best of our knowledge, our study is the first to investigate the impact of all four types of organizational structure on the performance and risk-taking behavior. In addition, the deregulation of financial services in Taiwan sparked an unprecedented wave of structural changes in these markets as firms sought to position themselves to succeed in the new regulatory environment. Second, it is apparent that different Taiwan's insurance companies choose different business strategies, which allow us to investigate the impact of business strategy on performance and risk-taking behavior.

We find that financial holding companies are less profitable and less efficient than are local independent companies. The merger and acquisition companies and foreign subsidiary companies insurance companies, on average, underwrite more risky policies than local independent insurance companies. Second, we find that business strategies have significant impacts on the efficiency, profitability, and risk taking of insurers. Specialized life insurers tend to have lower underwriting risk and are more cost efficient, but they are also less profitable than diversified life insurers.

Our article extends the existing literature in many ways. First, we examine which form of organizational structure is the most efficient by focusing on an alternative environment, Taiwan insurance industry, while most literature focuses on either U.S. or Japan. Second, four different types of organizational structures: financial holding company, merger and acquisition company, foreign subsidiary and local company are investigated. Finally, we also extend the prior studies by simultaneously examining the impact of organization structure and business strategies on multiple measurements: performance, profitability, and risk taking.

The rest of the paper is divided as follows. In Section 2, we provide some background about the Taiwanese life insurance industry. We then review prior literature and develop our hypotheses accordingly in Section 3. Section 4 contains the data and methodology; Section 5 includes the empirical results. We conclude in Section 6.

\subsection{Background of the Taiwanese Life Insurance Industry}

The deregulation of financial services in Taiwan sparked an unprecedented wave of structural changes in these markets as firms sought to position themselves to succeed in the new regulatory environment. The insurance commissioner permitted entry by foreign companies into the insurance market as of 1987, and in 1993, the government allowed new domestic life insurance companies to enter the insurance market. In the early 2000s, the Taiwanese Congress passed the Merger Law of Financial Institutions and the Financial Holding Company Act, designed to enhance the economic efficiency of financial service industries. Furthermore, the remarkable wave of mergers and acquisitions in the insurance industry during the 1990s differentiates this environment from the conditions that prevailed in other decades. There were two merger and acquisition cases occurred in 2000.1 Finally, the insurance companies that are members of financial holding companies are referred as financial holding insurance companies (FHC) in this paper2, which are similar to keiretsu insurance companies in Japan in terms of their organizational structure3, except that they do not use a cross-ownership of shares system. These FHCs maintain the largest assets among all types of life insurance companies, as Figure 1 shows in its summary of the total asset and premium revenues of the Taiwanese life insurance industry during 1977-2002. Total asset and premium revenues increased slightly from 1987 (when foreign entrants were allowed into the market) through 2002. Thus, deregulation, entrance of foreign companies and new domestic competitors, and incorporation of FHCs appear to have had impacts on the operational scale and premium revenues of life insurance companies.

\footnotetext{
${ }^{1}$ The first case is Georgia Life merged with ING-Aetna Life. The other case was that Aegon Levensverzekering Life acquired Transamerica Occidental Life and The National Mutual Life Association of Australasian.

${ }^{2}$ As of today, there are 14 financial holding companies in Taiwan and the five financial holding insurance companies included in this paper are Cathay Life, China Life, Shin Kong Life, Fubon Life, and Singfor Life.

${ }^{3}$ See Lai and Limpaphayom (2003) for a detailed description of keiretsu insurance companies.
} 


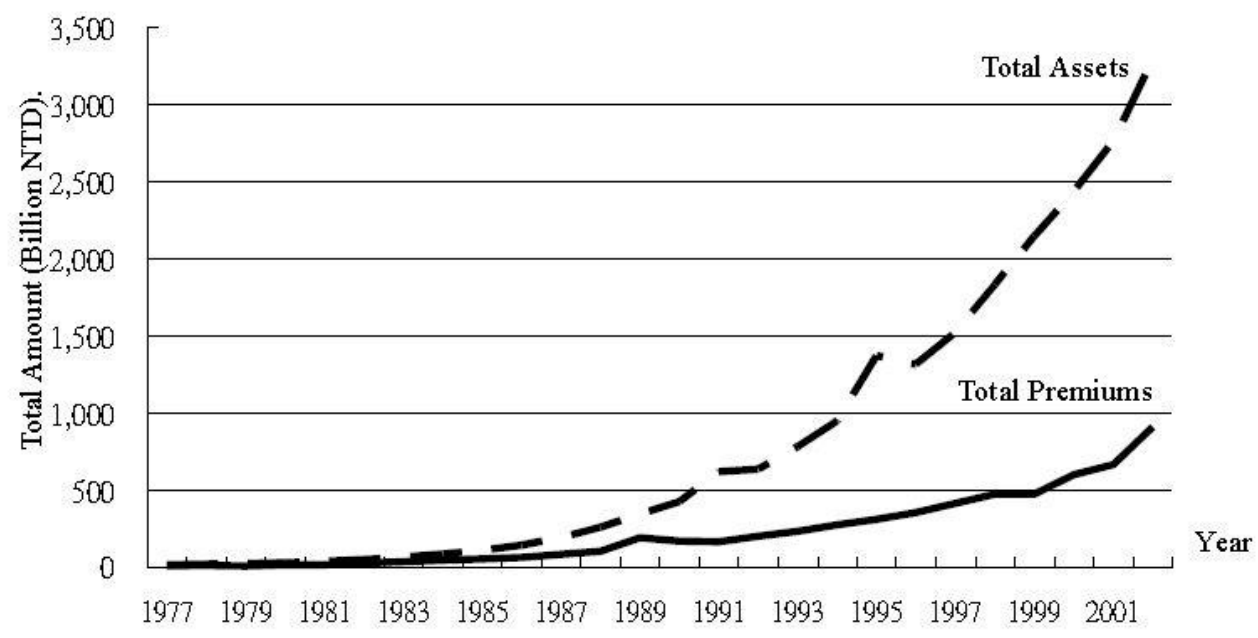

Figure 1 Taiwanese Life Insurance Industry Statistics (1977-2002)

The insurance industry in Taiwan provides an interesting environment for studying this issue. In Taiwan, different organizational forms coexist in the industry. There are four different types of organizational structures in Taiwanese insurance industry: financial holding company (FHC), firms that have been involved in mergers or acquisitions (M\&A), foreign subsidiary (FSC) and local insurance company (LIC). The financial holding company owns many subsidiaries, and thus owns a broad range of businesses. M\&A firms mean insurance firms that were acquired or merged with other firms. Foreign subsidiary is owned by foreign investors and is subject to local government and foreign government. Local insurance company is only subject to local government regulation. The analysis from different forms of insurers provides a richer understanding of the impact of organizational structure on insurers' performance and risk taking. Additionally, the Taiwan insurance industry has experienced a wave of structure changes as the Taiwanese Congress passed the Merger Law of Financial Institutions and the Financial Holding Company Act and some insurers were acquired or merged with other firms over the past years. Thus, the Taiwan insurance industry provides an interesting setting for examining this area of research.

\section{Literature Review and Research Hypotheses}

Berle and Means (1932) were among the first to focus on the relationship between the structure of a firm's property rights and its real activities. Coase (1960) also points out that agency costs arising from the incentive conflicts among parties to a contract, including monitoring and opportunity costs, are negligible in a frictionless market. In this sense, the organizational structure has no impact on firm performance. Jensen and Meckling (1976) continue this stream of research and contend that agency costs result from incentive conflicts among parties to a contract and are rarely zero. Mayers and Smith (1981) and Fama and Jensen (1983b) therefore examine incentive conflicts among contracting parties for different ownership and organizational structures.

The impact of organizational structure on performance also emerges as an important topic for banking and insurance studies, most of which find that each form has its own comparative advantages. For example, Mayers and Smith (1981, $1986,1988,1992)$ contend that the survival of both stock and mutual organizational forms reflects the relative efficiencies of these different forms in controlling their particular agency problems. Similarly, Cummins, Weiss, and $\mathrm{Zi}$ (1999) examine the efficiency of different organizational forms in the U.S. property-liability insurance industry to test the managerial discretion hypothesis (Mayers and Smith, 1981, 1988) and the expense preference hypothesis (Williamson, 1963). Their finding is consistent with the managerial discretion hypothesis: Stock insurance firms dominate lines of business that require more managerial discretion, whereas mutual insurance companies are more successful in lines that demand less managerial discretion.

We also believe that financial holding companies are more efficient than independent firms in certain respects and independent firms are more efficient than financial holding companies in other respects. Proponents of conglomeration argue that benefits of diversification include cost scope economies from sharing fixed inputs (e.g., Teece, 1980). Conglomeration may also enhance financial efficiency by channeling funds from relatively low-cost sources to better investment projects (e.g., Williamson, 1970). In addition, conglomerate firms may diversify risk through operating broad range of business and thus reduce the expected cost of financial distress. On the other hand, independent firms may be more efficient than financial holding companies. Some studies find the existence of diversification discount and conclude that diversification may destroy firm value (Berger and Ofek 1995, Servaes 1996). For instance, conglomerate 
firms may incur coordination and administrative costs from offering a broad range of business. Additionally, management of highly diversified firms may find it difficult to properly manage increasing dissimilar business units (Jones and Hill, 1988). Therefore, we expect that independent firms may be more efficient than conglomerate firms. Empirically, Lai and Limpaphayom (2003) and Jeng and Lai (2005) find that keiretsu insurers exhibit greater cost efficiency than do nonspecialized, independent insurance companies. Furthermore, Grabowski, Rangan, and Rezvanian (1993) indicate that branch banking might lead to greater efficiency than keeping banks separate in a financial holding company. In examining the impact of acquisitions on efficiency in the U.S. life insurance industry, Cummins, Tennyson, and Weiss (1999) provide strong evidence that M\&A companies are more efficient than are non-M\&A companies. Similarly, Cummins and Xie (2008) find that M\&As were value-enhancing for US property-liability insurance industry. These findings are consistent with the existence of economies of scale and economies of scope are the most frequently cited motivations for takeover activities.

These previous studies suggest the existence of a relationship between organizational structures and firm performance is not clear a priori. Therefore, we propose a null hypothesis that no relationship exists between organizational structures and efficiency. That is, financial holding companies, merger and acquisition companies, foreign subsidiary companies, and local independent companies are all equally efficient. Rejection of the null hypothesis implies that one of organizational structures dominates the others in terms of its efficiency.

\subsection{Hypothesis I: No Relationship Exists Between Organizational Structures and Efficiency.}

Some studies also have investigated the impact of organizational structures on firm profitability. According to the modern theory of the firm, the organizational structure that survives in the long run is the one that provides the product at the lowest price but still covers its operational expenses. Therefore, organizational structures should influence firm profitability. Empirically, Lai and Limpaphayom (2003) find nonlife insurers operating in keiretsu groups earn higher profits than do independent nonlife insurers. Iannotta, Nocera, and Sironi (2007) document that privately held stock banks are more profitable than are mutual banks in European countries. These empirical findings suggest the profitability of firms structured differently will differ. Therefore, we propose a null hypothesis that no relationship exists between organizational structures and profitability. Financial holding companies, merger and acquisition companies, foreign subsidiary companies, and local independent companies are all equally profitable. Rejection of the null hypothesis implies that one of organizational structures dominates the others in terms of its profitability.

\subsection{Hypothesis II: No Relationship Exists Between Organizational Structures and Profitability.}

Because risk and return trade off, we should simultaneously consider both profit and risk-taking behaviors. An organizational structure may affect firm risk taking according to the incentive conflicts that emerge among parties to a contract in the different organizational structures. For example, the separation of fixed and residual claims in the stock ownership form might lead stock insurers to take more risk than mutual insurers, which mirrors the agency conflicts between owners and fixed claimholders. Both agency theories (Fama and Jensen, 1983a, 1983b; Mayers and Smith 1988, 1990) and adverse selection (Smith and Stutzer, 1990) theories imply the mutual form tends to relate to less risky activities, whereas the efficient risk-sharing argument (Doherty and Dionne, 1993; Doherty, 1991) indicates that mutual insurers may accept more risky clients. Empirically, Lamm-Tennant and Starks (1993) find that the stock form experiences higher underwriting risk than do mutual property-liability insurers. Similarly, Baranoff and Sager (2003) find that life stock insurers are associated with greater financial and asset risk than mutual insurers.

Cummins and Sommer (1996) reveal that the market deems insurance groups more risky than unaffiliated single insurance firms, which implies that FHCs might take more risk than single insurance firms. Brealey, Myers, and Allen (2003) also show that a M\&A strategy may not provide adequate opportunities for companies to diversify their risk. Thus, prior studies indicate that the choice of organizational structure influences the firm's risk taking. We advance a null hypothesis to test this potential influence on risk-taking behaviors.

\subsection{Hypothesis III: No Relationship Exists Between Organizational Structures and Risk-Taking Behavior.}

Business strategy (specialized versus diversified) also influences efficiency, because whereas specialized firms sell one or two product lines, diversified firms operate across many lines of business. Proponents of the specialized strategy argue that the human capital investments and coordination costs of specialized firms are lower than those of diversified firms, which makes these firms more cost efficient, all else being equal (Carr, Cummins, and Regan, 1999). For example, actuaries and the sales force can focus on one or two lines of business, which may increase overall firm efficiency. In addition, specialized firms can reduce the agency costs caused by cross-subsidization with weak subsidiaries (e.g., Amihud and Lev, 1981; Jensen, 1986; Wells, Cox, and Gaver, 1995; Berger et al., 2000). Cummins et al. (2003) thus find that specialized insurers are generally more efficient than diversified insurers in the U.S. insurance industry, and using Japanese nonlife insurer data, Jeng and Lai (2005) find that specialized independent firms enjoy advantages from their specialization. 
Yet proponents of the diversified strategy contend that these firms enjoy economies of scope by sharing inputs or providing "one-stop shopping" (e.g., Teece, 1980; Herring and Santomero, 1990; Gallo, Apilado, and Kolari, 1996; Calomiris, 1998). In this sense, a diversified strategy might provide greater efficiency, as Meador, Ryan, and Schellhorn (2000) show with U.S. life insurer data that indicate efficiency increases with product diversification. Overall, the previous results suggest that business strategy have an impact on firm efficiency. We advance the null hypothesis that no relationship exists between business strategy and efficiency. Rejection of the null hypothesis implies that one of business strategies dominates the others in terms of firm efficiency.

\subsection{Hypothesis IV: No Relationship Exists Between Business Strategy and Efficiency.}

Moreover, extensive literature considers the potential impact of diversification on firm value, which Martin and Sayrak (2003) summarize in three categories: (1) corporate diversification destroys the shareholder's wealth, (2) corporate diversification does not destroy the shareholder's wealth, and (3) corporate diversification creates the shareholder's wealth. Whether diversification creates or destroys wealth thus remains an unanswered question. Liebeskind and Opler (1993) and Comment and Jarrell (1995) find a positive relationship between returns and specialization, and more recently, Liebenberg and Sommer (2008) offer support for the strategic focus hypothesis using a sample of propertyliability insurers during 1995-2004, in which they find a diversification penalty of at least 1 percent of the return on assets or 2 percent of the return on equity. Elango, Ma, and Pope (2008) found that the relation between profitability and product diversification depends on an property-liability insurer's geographic diversification. According to these studies, we again offer a null hypothesis that suggests business strategies have no impact on profitability. Rejection of the null hypothesis implies that one of business strategies dominates the others in terms of firm profitability.

\subsection{Hypothesis V: No Relationship Exists Between Business Strategy and Profitability.}

Finally, because risk and return are trade-offs, we examine the impact of business strategy on insurer risk. Specialized insurers may suffer more underwriting risk associated with the more risky, specific claims of a single line. Life insurance products consist primarily of four categories - individual life insurance, health and accident insurance, annuity insurance, and group insurance - that vary in their operational and contractual complexity. Group insurance contracts are less risky than individual contracts, because they are underwritten with the group as the unit, and the adverse selection problem should be less severe than it is for individual insurance products (Kochhar, 1996; Baranoff and Sager, 2002, 2003). Among the various insurance products, health insurance may be the most risky, according to both prior research and insurance regulators (Baranoff and Sager, 2002). Unlike life insurance products, sold to provide predetermined death benefits, health insurance products offer a relatively uncertain future cash flow (Carr et al., 1999). Accordingly, we expect that the life insurance product mix varies in its risk levels, so our null hypothesis proposes that business strategy, in terms of the product mix (different lines of business), is not related to the underwriting risk of life insurance firms.

\subsection{Hypothesis VI: No Relationship Exists Between Business Strategy and Risk-Taking Behavior.}

\section{Data and Methodology}

In this section, we describe our data and the efficiency frontier methodology, including the stochastic frontier approach and data envelopment analysis approach.

\subsection{Data}

We use Taiwan's life insurance companies as our sample. The sample includes 26 life insurance companies ${ }^{4}$ during the period from 1977 to $2002^{56}$. Our data sources include the Annual Statistical Report of Life Insurance Review, provided by the Life Insurance Association of the Republic of China. Our sample accounts for approximately $97.54 \%$ of industry assets. To examine the impact of organizational structure on performance and risk-taking behaviors, we categorize our sample into four types of insurance companies: financial holding companies (FHC), merger and acquisition companies (M\&A), foreign subsidiary companies (FSC) and local independent companies (LIC).

\footnotetext{
4 The 26 firms are average numbers for the sample period.

${ }^{5}$ We focus on this time period because the Taiwan insurance market structure has been changed a lot after year 2002. First, The Taiwan congress enacted the Merger Law of financial institutions and the Financial Holding Company Act in 2000 and 2001, respectively. Second, the insurance industry in the Taiwan is currently experiencing a wave of bancassurance. The growth of first-year premium from the banking insurance agents has proceeds those from direct writers. Third, the product mix is also changed. For example, most life insurers that belong to financial holding company distribute relatively more interest-rate sensitive or investment-linked insurance products. These change may affect our results. Focusing on the time period allows for more homogeneity in the market conditions affecting life insurers.

${ }^{6}$ Because the size of our non-surviving life insurance firms over our sample period is small, it may not be appropriate to examine the effect based on surviving and non-surviving life insurance firms separately over our sample period.
} 
In Table 1, we present the characteristics of each insurance company and the sample period averages by types of firms. Panel A reports the results of FHC firms; Panel B reports the results of FSC firms; Panel C shows the results of LIC firms; and Panel D shows the results of M\&A firms. The FHCs are, on average, larger than the other types in terms of total assets; an average FHC holds total assets of Taiwanese NTD\$126,493 million. The overall mean of market shares (MS) of FHCs is $15.2 \%$, which suggests that FHCs also maintain larger market shares on average. Therefore, they play important roles in the Taiwanese life insurance market. Moreover, Table 1 shows that life insurance products are the most important product line, representing more than 50 percent of the total premiums for all types of firms in our sample period. The percentages of total premium in life insurance lines (LIFEP) range from 52.5 to 64.2.

Furthermore, the life insurance market in Taiwan appears relatively concentrated. The FHCs also have the highest average equity to liability ratio (EQTL) (3.42 percent), whereas FSCs exhibit the lowest EQTL (1.235 percent), such that foreign subsidiaries appear to have greater financial leverage. Finally, the FSCs, on average, indicate the highest underwriting risk (UNDERW-RISK), whereas FHCs reveal the lowest (4.93 and 0.782, respectively).

Table 1. Characteristics of Life Insurance Companies in Taiwan

\begin{tabular}{|c|c|c|c|c|c|c|c|c|}
\hline Company & Total asset ${ }^{*}$ LIFEP & HAP & GROUPP & MS & FOCUS & EQTL & UNDERW- & Converted \\
\hline & & & & & & & RISK & $\begin{array}{l}\text { /Established } \\
\text { year }\end{array}$ \\
\hline
\end{tabular}

Panel A: FHC Firms $(n=5)$

\begin{tabular}{lllllllllll}
\hline Cathay Life & 374,595 & 0.711 & 0.097 & 0.02 & 0.467 & 0.788 & 0.066 & 0.011 & 2001 & 2002 \\
China Life & 27,155 & 0.561 & 0.097 & 0.078 & 0.021 & 0.572 & 0.29 & 0.776 & 2002 \\
Shin Kong Life & 166,762 & 0.739 & 0.079 & 0.006 & 0.255 & 0.797 & 0.095 & 0.165 & 2.167 & 2001 \\
Fubon Life & 58,094 & 0.593 & 0.126 & 0.021 & 0.014 & 0.549 & 2.129 & 1.267 \\
Singfor & 5,857 & 0.606 & 0.112 & 0.016 & 0.004 & 0.677 & 14.519 & 1.689 & 2002 \\
Average & 126,493 & 0.642 & 0.102 & 0.028 & 0.152 & 0.677 & 3.420 & 0.782 & - \\
\hline
\end{tabular}

Panel B: FSC Firms ( $n=9)$

\begin{tabular}{llllllllll}
\hline Nan Shan Life & 110,204 & 0.585 & 0.2 & 0.061 & 0.109 & 0.524 & 0.175 & 0.066 & 1963 \\
Prudential Life & 5,453 & 0.695 & 0.128 & 0.002 & 0.003 & 0.733 & 1.435 & 1.185 & 1989 \\
Metropolitan & 4,883 & 0.755 & 0.116 & 0.004 & 0.004 & 0.743 & 1.111 & 1.339 & 1988 \\
Connecticut General & 1,068 & 0.436 & 0.448 & 0.005 & 0.001 & 0.442 & 0.359 & 9.409 & 1989 \\
American Life & 573 & 0.593 & 0.264 & 0 & 0.001 & 0.553 & 1.89 & 10.062 & 1990 \\
The Manufacturers & 900 & 0.634 & 0.156 & 0.006 & 0.001 & 0.623 & 1.707 & 9.086 & 1991 \\
New York & 5,232 & 0.724 & 0.114 & 0 & 0.004 & 0.755 & 3.999 & 0.892 & 1991 \\
Winterthur & 2,278 & 0.603 & 0.308 & 0.004 & 0.002 & 0.483 & 0.32 & 2.766 & 1992 \\
Zurich & 1,956 & 0.371 & 0.201 & 0.011 & 0.11 & 0.154 & 0.12 & 9.611 & 1993 \\
Average & 14,727 & 0.600 & 0.215 & 0.010 & 0.026 & 0.711 & 1.235 & 4.935 & - \\
\hline
\end{tabular}

(Continued) 
Table 1. Continued.

\begin{tabular}{|c|c|c|c|c|c|c|c|c|c|}
\hline Company & Total asset $^{*}$ & LIFEP & HAP & GROUPP & MS & FOCUS & EQTL & $\begin{array}{l}\text { UNDERW- } \\
\text { RISK }\end{array}$ & $\begin{array}{c}\text { Converted } \\
\text { /Established } \\
\text { year }\end{array}$ \\
\hline \multicolumn{10}{|c|}{ Panel C: LIC Firms $(n=7)$} \\
\hline Taiwan Life & 24,518 & 0.533 & 0.102 & 0.046 & 0.026 & 0.578 & 0.177 & 0.118 & 1947 \\
\hline Kuo Hua Life & 26,805 & 0.666 & 0.152 & 0.059 & 0.045 & 0.638 & 0.321 & 0.169 & 1963 \\
\hline Global Life & 4,613 & 0.59 & 0.206 & 0.006 & 0.005 & 0.569 & 3.56 & 2.013 & 1993 \\
\hline Mass Mutual Mercurie & 20,587 & 0.576 & 0.268 & 0.003 & 0.017 & 0.521 & 2.313 & 1.041 & 1993 \\
\hline Sinon & 4,206 & 0.661 & 0.121 & 0.007 & 0.002 & 0.673 & 4.322 & 1.046 & 1993 \\
\hline Allianz President & 6,506 & 0.709 & 0.15 & 0.007 & 0.004 & 0.654 & 2.15 & 0.583 & 1995 \\
\hline Average & 14,809 & 0.633 & 0.155 & 0.026 & 0.018 & 0.627 & 1.852 & 0.754 & - \\
\hline \multicolumn{10}{|c|}{ Panel D: M\&A Firms $(n=5)$} \\
\hline ING-Aetna Life & 46,064 & 0.604 & 0.302 & 0.005 & 0.038 & 0.473 & 0.048 & 0.092 & 2000 \\
\hline Georgia & 3,319 & 0.524 & 0.247 & 0.005 & 0.003 & 0.577 & 3.132 & 1.176 & 2000 \\
\hline Transamerica Occidental & 1,864 & 0.435 & 0.299 & 0.005 & 0.002 & 0.544 & 0.123 & 3.571 & 2000 \\
\hline NMLAA $^{* *}$ & 2,310 & 0.525 & 0.134 & 0.016 & 0.001 & 0.665 & 0.925 & 7.305 & 2000 \\
\hline $\begin{array}{l}\text { Aegon } \\
\text { Levensverzekering }\end{array}$ & 2,052 & 0.538 & 0.233 & 0 & 0.001 & 0.585 & 3.474 & 4.876 & 2000 \\
\hline Average & 11,122 & 0.525 & 0.243 & 0.006 & 0.009 & 0.569 & 1.540 & 3.404 & - \\
\hline
\end{tabular}

This table reports the sample period averages for the firm characteristics for each company during 1977-2002. FHC = financial holding company; FSC = foreign subsidiary company; LIC = local independent company; M\&A = merger and acquisition company. LIFEP = life insurance premium share of total premium; HAP $=$ health and accident insurance premium share of total premium; GROUPP = group insurance premium share of total premium. MS = market share. FOCUS = line of business Herfindahl index. EQTL = equity-liability ratio. UNDERWRISK = risk of claim measured by coefficient of variation of three years claim.

* Total assets expressed in millions of New Taiwanese Dollars.

** NMLAA is the National Mutual Life Association of Australasian.

\subsection{Methodology}

Our main focus is to consider the impact of organizational structure and business strategy on performance and risk taking by life insurers. Our discussions focus on efficiency measurement because profitability and measurement of risk-taking can easily be calculated.

The frontier efficiency method flows directly from the production frontier of microeconomic theory. That is, the production frontier indicates the minimum inputs needed to produce a given output vector for a firm operating at full efficiency. Traditional frontier approaches to measuring efficiency include the econometric (or parametric) and mathematical programming (or nonparametric) approaches (Berger and Humphrey, 1997; Cummins and Weiss, 2000). The main advantage of the former is that it does not count random error as inefficiency; by separating random error and inefficiency, the econometric approach allows decision-making units to miss the best practice frontier because of either random error or inefficiency. However, for this approach, researchers need to specify the functional form (e.g., translog cost function) and distributional assumptions about inefficiency terms. The main advantage of the mathematical programming approach (e.g., data envelopment analysis, DEA) is that it avoids the potential specification error problem; however, in DEA, the estimated efficiency scores may not be accurate if the characteristics of the sample firms are not homogeneous. Cummins and Weiss (2000) offer a detailed discussion of advantages and disadvantages of these two approaches. We use both the X-efficiency methodology (parametric) and the DEA approach (nonparametric). 


\subsection{Measuring X-Efficiency}

The measure of $\mathrm{X}$-inefficiency requires a specification of a specific distribution for the residuals. We follow Battese and Coelli $(1992,1995)$ and adopt a stochastic frontier approach (SFA), which previously has been applied to study bank and insurance efficiency (e.g., Aigner, Lovell, and Schmidt, 1977; Bauer, Berger, and Humphrey, 1993; Bauer and Hancock, 1993; Cebenoyan, Cooperman, Register, and Hudgins, 1993; Mester, 1993). Traditional studies assume a translog cost function as the cost functional form:

$$
\begin{aligned}
& \ln (C)=\alpha_{0}+\sum_{i=1}^{n} \beta_{i} \ln \left(y_{i}\right)+\sum_{j=1}^{m} \gamma_{j} \ln \left(w_{j}\right)+\frac{1}{2} \sum_{i=1}^{n} \sum_{h=1}^{n} \beta_{i h} \ln \left(y_{i}\right) \ln \left(y_{h}\right) \\
& +\frac{1}{2} \sum_{j=1}^{m} \sum_{k=1}^{m} \gamma_{j k} \ln \left(w_{j}\right) \ln \left(w_{k}\right)+\sum_{i=1}^{n} \sum_{j=1}^{m} \delta_{i j} \ln \left(y_{i}\right) \ln \left(w_{j}\right)+\left(v+u_{1}\right)
\end{aligned}
$$

where $\ln (C)$ is the logarithm of total cost; $y_{i}$ are outputs, $i=1, \ldots, \mathrm{n} ; w_{j}$ are input prices, $j=1, \ldots, \mathrm{m} ; v$ is a random disturbance terms, assumed to be normally distributed and independent of $u$; and $u$ is cost inefficiency, which represents the deviation from the cost frontier and is assumed to follow a half-normal distribution.

The total costs are defined as all operating costs, including labor, physical capital, and claim expenses (Weiss, 1986; Gardner and Grace, 1993; Rai, 1996; Hao and Chou, 2005). We follow prior literature (e.g., Blair, Jackson, and Vogel, 1975; Weiss, 1986; Grace and Timme, 1992; Gardner and Grace, 1993; Cummins and Weiss, 2000) and use traditional proxies for the outputs, inputs, and input prices for life insurers. We use the gross premiums as the proxy for the outputs, on the basis of the rationale that premiums are associated with the technical activity of insurance companies. Premiums thus reflect the ability of insurance companies to sell products, select customers, and accept risks. This approach is consistent with that used by previous insurance studies, including Blair et al. (1975), Weiss (1986), Grace and Timme (1992), and Gardner and Grace (1993). Because underwriting risk and service intensity vary by lines of insurance, we disaggregate outputs into three categories: ordinary life insurance premiums, accident and health premiums, and group life insurance premiums. We also use the invested assets as an output proxy to reflect the financial intermediation service provided by life insurance companies.

The insurance inputs can be classified into three categories: labor, physical capital, and claims. The price of labor is the sum of compensation to agents and salaries, divided by the number of employees. The price of capital is the amount of capital expenditures (i.e., depreciation plus administrative expenses), divided by fixed assets. Finally, the price of claims is the amount of benefits paid to policyholders, divided by the number of policies. Estimated X-efficiency thus can be interpreted as the ratio of the minimum costs that could have been expended to produce a given output to the actual costs expended (Berger, 1993). Our efficiency measure thus corresponds to the formula developed in Berger (1993):

$$
\operatorname{SFAH} H_{i t}=\operatorname{EXP}\left(\operatorname{Min}\left(\varepsilon_{i t}\right)-\varepsilon_{i t}\right),
$$

where $S F A H_{i t}$ is the relative X-efficiency score. The estimated X-efficiency score ranges from 0 and 1 , so an efficient firm earns a score of 1 , whereas an inefficient firm has a score between 0 and 1.

\subsection{Data Envelopment Analysis}

The basic idea of the DEA derives from the concept of the production frontier of microeconomic theory, according to which efficient firms operate on the frontier. The firm's efficiencies can be estimated relative to the frontier, and an insurance firm is fully cost efficient if it uses the cost-minimizing combination of inputs to attain a certain level of outputs. Cost efficiency scores also can be decomposed into technical efficiency (TE) and allocative efficiency (AE). The former measures the firm's ability to generate maximum outputs for a given level of inputs, whereas the latter assesses its ability to use the cost-minimizing combination of the input vector, given certain input prices. The efficiency scores ranges from 0 to 1 , and firms operating on the frontier are fully efficient (score $=1$ ), whereas those that do not operate on the frontier are inefficient $(0<$ score $<1)$. A detailed description of the DEA approach appears in Cummins and Weiss (2000).

\subsection{Descriptive Statistics for Outputs and Inputs}

In Table 2, the summary statistics show that the FHCs are the largest insurers in the sample in terms of total cost and all outputs. Furthermore, the level of total costs and outputs for different organizational forms tend to differ. In particular, 
FSCs pay the highest labor costs relative to other types of companies, which implies that their efficiency may be adversely affected by their high labor costs. The results of Wilcoxon tests also indicate that the labor costs of LICs are significantly lower than those of FHCs; however, FHCs and FSCs enjoy lower costs of capital than do LICs and M\&As. Apparently, capital is more expensive inside than outside Taiwan, and these higher capital costs negatively influence the efficiency of LICs. With regard to another source of the input prices, our evidence shows that FHCs experience a higher level of claims than do other types. Overall then, the results indicate that each type suffers an input cost that is higher than the others'. We thus cannot determine which types of companies have cheaper total costs than other types.

Table 2 Descriptive Statistics of Output and Input Variables

\begin{tabular}{|c|c|c|c|c|c|c|c|c|c|c|c|c|}
\hline & \multicolumn{6}{|c|}{ Panel A: FHC vs. M\&A } & \multicolumn{6}{|c|}{ Panel B : FHC vs. FSC } \\
\hline & $\mathrm{FHC}$ & $M \& A$ & T test & P-value & $\mathrm{Z}$ test & Wilcoxon & $\mathrm{FHC}$ & FSC & $\mathrm{T}$ test & $P$-value & $Z$ test & Wilcoxon \\
\hline $\mathrm{TC}$ & 43,179 & 11,814 & 29.800 & $0.001^{* * * * *}$ & -2.197 & $0.028^{* * *}$ & 43,179 & 1,228 & 92.815 & $0.000^{* * * * *}$ & -1.931 & $0.053^{*}$ \\
\hline $\mathrm{Y}_{1}$ & 64,036 & 19,728 & 21.163 & $0.002^{* k * k *}$ & -2.366 & $0.018^{* * *}$ & 64,036 & 2,340 & 12.376 & $0.006^{\text {****** }}$ & -2.158 & $0.031^{* * *}$ \\
\hline $\mathrm{Y}_{2}$ & 11,737 & 8,518 & 3.273 & $0.082^{*}$ & -1.521 & 0.128 & 11,737 & 572 & 17.313 & $0.003^{* * k * k}$ & -2.442 & $0.015^{* * *}$ \\
\hline $\mathrm{Y}_{3}$ & 564 & 101 & 5.970 & $0.027^{* * *}$ & -2.366 & $0.018^{* * * *}$ & 564 & 19 & 7.832 & $0.016^{* * *}$ & -1.42 & 0.156 \\
\hline $\mathrm{Y}_{4}$ & 17,505 & 3,110 & 29.840 & $0.001^{*: k * *}$ & -2.197 & $0.028^{* * * *}$ & 17,505 & 272 & 117.281 & $0.000^{* * * * *}$ & -1.874 & $0.061^{*}$ \\
\hline $\mathrm{P}_{\mathrm{W}}$ & 519,223 & 963,009 & -1.483 & $0.091^{*}$ & 1.183 & 0.237 & 519,223 & $1,759,228$ & -4.355 & $0.002^{* * * *}$ & 2.028 & $0.043^{* * *}$ \\
\hline $\mathrm{P}_{\mathrm{K}}$ & 0.381 & 8.844 & -1.038 & 0.167 & 0.845 & 0.398 & 0.381 & 0.43 & -0.216 & 0.417 & 0.676 & 0.499 \\
\hline$P_{B}$ & 8,373 & 4,161 & 1.918 & $0.048^{* * *}$ & -1.183 & 0.237 & 8,373 & 2,013 & 8.645 & $0.000^{* * * * * *}$ & -2.366 & $0.018^{* * *}$ \\
\hline
\end{tabular}

Table 2-Continued

\begin{tabular}{|c|c|c|c|c|c|c|c|c|c|c|c|c|}
\hline & \multicolumn{6}{|c|}{ Panel C: FHC vs. LIC } & \multicolumn{6}{|c|}{ Panel D : LIC vs. M\&A } \\
\hline & FHC & LIC & T test & P-value & $Z$ test & Wilcoxon & LIC & $M \& A$ & T test & P-value & $Z_{\text {test }}$ & Wilcoxon \\
\hline $\mathrm{TC}$ & 43,179 & 15,439 & 9.106 & $0.012^{* * *}$ & -3.351 & $0.001^{\text {* } *: * *}$ & 15,439 & 11,814 & 1.523 & 0.267 & -2.366 & $0.018^{* * * *}$ \\
\hline $\mathrm{Y}_{1}$ & 64,036 & 25,758 & 24.884 & $0.002^{k * k * k}$ & -2.045 & $0.041^{* * *}$ & 25,758 & 19,728 & 3.388 & $0.077^{*}$ & -2.366 & $0.018^{* * *}$ \\
\hline $\mathrm{Y}_{2}$ & 11,737 & 6,050 & 12.952 & $0.006^{\text {*k:k*k}}$ & -1.761 & $0.078^{*}$ & 6,050 & 8,518 & -2.096 & 0.171 & -1.69 & $0.091^{*}$ \\
\hline $\mathrm{Y}_{3}$ & 564 & 406 & 3.088 & $0.091^{*}$ & -3.294 & $0.001^{\text {**:*k* }}$ & 406 & 101 & 8.791 & $0.013^{\text {**k }}$ & -2.366 & $0.018^{* * *}$ \\
\hline $\mathrm{Y}_{4}$ & 17,505 & 4,676 & 19.406 & $0.003^{*-k * k}$ & -3.181 & $0.001^{\text {**k*k }}$ & 4,676 & 3,110 & 1.661 & 0.239 & -1.859 & 0.063 \\
\hline $\mathrm{P}_{\mathrm{W}}$ & 519,223 & 472,654 & 0.545 & 0.296 & 3.408 & $0.001^{* * k * k}$ & 472,654 & 963,009 & -1.696 & $0.070^{*}$ & 2.197 & $0.028^{* k *}$ \\
\hline$P_{K}$ & 0.381 & 5.374 & -6.256 & $0.000^{* k * k * k}$ & 2.422 & $0.015^{* * *}$ & 5.374 & 8.844 & -0.424 & 0.343 & 1.183 & 0.237 \\
\hline $\mathrm{P}_{\mathrm{B}}$ & 8,373 & 4,200 & 5.511 & $0.000^{* \text { *k:k* }}$ & 2.556 & $0.011^{\text {**** }}$ & 4,200 & 4,161 & 0.018 & 0.493 & -0.676 & 0.499 \\
\hline
\end{tabular}

Table 2-Continued

\begin{tabular}{|c|c|c|c|c|c|c|c|c|c|c|c|c|}
\hline & \multicolumn{6}{|c|}{ Panel E : FSC vs. M\&A } & \multicolumn{6}{|c|}{ Panel F : FSC vs. LIC } \\
\hline & FSC & $M \& A$ & T test & P-value & $Z$ test & Wilcoxon & FSC & LIC & $T$ test & P-value & $Z$ test & Wilcoxon \\
\hline $\mathrm{TC}$ & 1,228 & 11,814 & -7.096 & $0.019^{* * *}$ & -0.507 & 0.612 & 1,228 & 15,439 & 4.111 & $0.054 *$ & -2.809 & $0.005^{* * * * *}$ \\
\hline $\mathrm{Y}_{1}$ & 2,340 & 19,728 & -4.346 & $0.049^{* * *}$ & -0.507 & 0.612 & 2,340 & 25,758 & -4.161 & $0.053^{*}$ & -5.139 & $0.000^{* * * * *}$ \\
\hline $\mathrm{Y}_{2}$ & 572 & 8,518 & -5.966 & $0.027^{* * *}$ & -1.014 & 0.31 & 572 & 6,050 & -26.430 & $0.001^{* * k * k}$ & -4.514 & $0.000^{* * * * *}$ \\
\hline $\mathrm{Y}_{3}$ & 19 & 101 & -8.555 & $0.013^{* * *}$ & -1.183 & 0.237 & 19 & 406 & -12.261 & $0.007^{* k * k *}$ & -5.278 & $0.000^{* * * * *}$ \\
\hline $\mathrm{Y}_{4}$ & 272 & 3,110 & -7.758 & $0.016^{* * *}$ & -0.338 & 0.735 & 272 & 4,676 & -5.631 & $0.030^{* * *}$ & -3.293 & $0.001^{* * * * *}$ \\
\hline $\mathrm{P}_{\mathrm{W}}$ & $1,759,228$ & 963,009 & 2.007 & $0.034^{* * *}$ & 1.992 & $0.046^{* * *}$ & $1,759,228$ & 472,654 & 4.696 & $0.002^{*: k * k}$ & 2.366 & $0.018^{* * *}$ \\
\hline$P_{K}$ & 0.43 & 8.844 & -0.976 & 0.183 & 1.153 & 0.249 & 0.43 & 5.374 & -6.043 & $0.000^{* * k * *}$ & 0 & 0.99 \\
\hline$P_{B}$ & 2,013 & 4,161 & -0.999 & 0.178 & 1.153 & 0.249 & 2,013 & 4,200 & -3.604 & $0.001^{\text {*k:k*k}}$ & 0.507 & 0.612 \\
\hline
\end{tabular}


Note: This table presents the means of the outputs and input price for various types of insurance companies. The null hypothesis is that the means of the variables will be equal for the different types of companies. FHC $=$ financial holding company; FSC = foreign subsidiary company; LIC = local independent company; $\mathrm{M} \& \mathrm{~A}=$ merger and acquisition company. $\mathrm{TC}=$ total cost. $\mathrm{Y}_{1}=$ ordinary life insurance premiums; $\mathrm{Y}_{2}=$ accident and health premiums, $\mathrm{Y}_{3}=$ group life insurance premiums; $\mathrm{Y}_{4}=$ investments. $\mathrm{P}_{\mathrm{W}}=$ Prices of labor (compensation to agents and salaries/number of employees); $\mathrm{P}_{\mathrm{K}}=$ prices of physical capital (capital expenditures/fixed assets); $\mathrm{P}_{\mathrm{B}}=$ prices of claims (benefits paid/number of policies). The data come from the Life Insurance Association of the Republic of China, 2000 to 2002. The $\mathrm{Y}_{1}, \mathrm{Y}_{2}, \mathrm{Y}_{3}, \mathrm{Y}_{4}$, and TC values are expressed in million NTD; the $\mathrm{P}_{\mathrm{B}}, \mathrm{P}_{\mathrm{K}}$, and $\mathrm{P}_{\mathrm{W}}$ values are expressed in NTD.

*Statistically significant at the $10 \%$ level. ** Statistically significant at the $5 \%$ level. *** Statistically significant at the $1 \%$ level.

\subsection{Regression Analysis}

We use three equations (Equations 3, 5, and 6) to test our hypotheses. Specifically, the dependent variables for the three equations are efficiency scores, profitability, and risk-taking behavior proxy, respectively. Some dependent variables in one equation may be independent variables in another equation; for example, both profitability and risk-taking behavior can be endogenous variables, which is consistent with the conventional wisdom that risk and return are trade-offs. Therefore, we use a seemingly unrelated regression approach. We detail all three regression models and discuss their dependent and independent variables.

\subsubsection{Efficiency Regression Model}

Equation (3) tests the relationship between organizational structure (business strategy) and efficiency:

$$
\begin{aligned}
\text { Efficiency Scores } & =\alpha+\beta_{1} B H C+\beta_{2} M \& A+\beta_{3} F S C+\beta_{4} F O C U S \\
& +\beta_{5} L T A+\beta_{6} L I F E P+\beta_{7} H A P+\beta_{8} G R O U P P+\beta_{9} E Q T L+\varepsilon
\end{aligned}
$$

The dependent variable is the estimated cost X-efficiency scores (SFAH) and DEA cost efficiency scores (DEA-CE) of a life insurance company. The most important independent variables are organizational structure (FHC, M\&A, and FSC) and business strategy (FOCUS), where FHC $=1$ if the insurance company is a member of financial holding company, and 0 otherwise; $\mathrm{M} \& \mathrm{~A}=1$ if the insurance company is a merger and acquisition insurance company, and 0 otherwise; and $\mathrm{FSC}=1$ if the insurance company is a foreign subsidiary company, and 0 otherwise. The omitted category is local independent life insurance companies. As we discussed, the most efficient organization should deliver the desired product at the lowest possible costs.

Following Meador et al. (2000), we use the firm's line of business Herfindahl index as a proxy for a specialized strategy (FOCUS):

$$
F O C U S=\frac{Y_{1}^{2}+Y_{2}^{2}+Y_{3}^{2}+Y_{4}^{2}}{\left(Y_{1}+Y_{2}+Y_{3}+Y_{4}\right)^{2}},
$$

where $Y_{1}$ is ordinary life insurance premiums; $Y_{2}$ is accident and health insurance premiums; $Y_{3}$ is group life insurance premiums; and $Y_{4}$ is group accident and health insurance premiums. When an insurance company focuses on one line of business, its FOCUS variable equals 1, which demonstrates that it adopts a very focused or specialized strategy.

The control variables include size (LTA), lines of insurance (LIFEP, HAP, GROUPP), and the equity-to-liability ratio (EQTL). We measure size as the log of the firm's total assets. Hao and Chou (2005) find positive influences of life insurer size on scale efficiency. Following Cummins et al. (1999), we include the lines of insurance to control for the impact of the product mix on performance; the different lines may require different inputs to produce the same unit of outputs. The proxies we adopt for the lines of business include the individual life insurance premium share of the total premiums (LIFEP), health and accident insurance premium share of the total premiums (HAP), and group insurance premium share of the total premiums (GROUPP). We use the EQTL ratio as a proxy for leverage; Meador et al. (2000) find a negative link between the EQTL and efficiency scores. We also provide the definitions of all proxies used in the regression analysis and their measures in the Appendix (Table A.1).

\subsubsection{Profitability Regression Model}

Equation (5) reflects the relationship between organizational structure (business strategy) and profitability: 


$$
\begin{aligned}
R O E= & \alpha+\beta_{1} B H C+\beta_{2} M \& A+\beta_{3} F S C+\beta_{4} F O C U S+\beta_{5} U N D E R W R I S K+\beta_{6} S F A H \\
& +\beta_{7} L T A+\beta_{8} L I F E P+\beta_{9} H A P+\beta_{10} G R O U P P+\beta_{11} E Q T L+\beta_{12} M S+\varepsilon
\end{aligned}
$$

The dependent variable (ROE) is defined as net income over equity. We take the book value of ROE as a proxy for profitability, ${ }^{7}$ as is common in prior literature (e.g., Cummins and Rubio-Misas, 2006). The key independent variables are organizational structure (FHC, M\&A, and FSC) and business strategy (FOCUS).

The control variables in Equation (5) are similar to those in Equation (3), with a few exceptions. Because return and risk may be endogenous variables, according to prior literature and the conventional wisdom, we include the proxy for underwriting risk (UNDERWRISK). The efficiency score (SFAH) serves as a control for the possible influence of cost efficiency on profitability, because a more efficient firm might be more profitable (e.g., Cummins and Zi, 1998; Cummins and Nini, 2002). Berger and Mester (1997) also suggest an indirect relation between cost efficiency and profit efficiency: If markets are competitive, firms may gain more revenues from providing higher quality products. In this case, profit efficiency can be improved by offsetting the extra costs of producing higher quality with higher revenues. Finally, the profitability regression model takes into account market share, calculated as the total premiums earned by the insurance firm divided by the total premiums of the life insurance industry, as another control variable. Gale and Branch (1982), Smirlock, Gilligan, and Marshall (1984), and Stevens (1990) all indicate that larger-scale companies achieve greater market shares and profits than other types of companies; Gardner and Grace (1993) and Meador et al. (2000) also argue that higher market share firms realize market power in terms of pricing, which improves their profitability.

\subsubsection{Risk-Taking Regression Model}

Equation (6) entails the relationship between organizational structure (business strategy) and risk-taking behavior:

$$
\begin{gathered}
\text { UNDERWRISK }=\alpha+\beta_{1} F H C+\beta_{2} M \& A+\beta_{3} F S C+\beta_{4} F O C U S+\beta_{5} L T A+\beta_{6} L I F E P+ \\
{ }_{7} H A P+\beta_{8} G R O U P P+\beta_{9} E Q T L+\beta_{10} M S+\varepsilon
\end{gathered}
$$

The dependent variable is underwriting risk estimates (UNDERWRISK). We use the coefficient of variation in the claims as the proxy for the degree of the underwriting risk. Because we define claims as occurred losses, their variation should correlate highly with the variance of an insurer's losses and offer a helpful proxy for cash flow uncertainty (Lamm-Tennant and Starks, 1993). Again, the most important independent variables are organizational structure and business strategy.

With regard to the control variables, Cummins and Sommer (1996) find that larger insurers take more risk, all else being equal, so we expect size (LTA) to relate positively to risk taking when everything else is equal. Health insurance is usually considered the most risky line of insurance among the insurance products. ${ }^{8}$ We expect a positive coefficient of the health and accident premium percentage (HAP) in the risk-taking regression model.

A few words also are in order regarding the model specification and econometric considerations for estimating regression models. We have used fixed-effect models to test the impact of organizational structure and business strategy on performance and risk taking. ${ }^{9}$ To test for multicollinearity, we use variance inflation factors and find no significant degree of correlation between the independent variables. In addition, we test for heteroscedasticity using the Lagrange multiplier test (LM test). The null assumption is homoscedastic. ${ }^{10}$ If the null assumption is accepted, we would estimate the regressions using the least squares regression; otherwise, we would estimate the coefficients using the random effects model (Breusch and Pagan, 1979).

To understand variation in performance and risk taking across different organizational structures, we first conduct a

\footnotetext{
${ }^{7}$ Because most life insurance companies in Taiwan are not publicly traded, we do not have the market value of the firm and we require a proxy for profitability.

${ }^{8}$ See, Baranoff and Sager (2002), for instance.

${ }^{9}$ Hausman's (1978) test suggests that fixed-effect models are superior to random-effect models.

${ }^{10}$ Breusch and Pagan (1979) have devised a LM test of the hypothesis that a model is homoscedastic if $a=0$. The
} model can be expressed as $\sigma_{i}^{2}=\sigma^{2} f\left(\alpha_{0}+\alpha Z_{i}\right)$, where $\mathrm{z}_{\mathrm{i}}$ is a vector of independent variables, and $\alpha$ is a random error term of the constant. 
univariate analysis. Next, we regress the efficiency, profitability, and risk-taking measures on a set of independent variables, including organizational forms, business strategy, and other firm characteristics.

\subsection{Univariate Results}

In Table 3, we report the means of the efficiency scores, ROE, and underwriting risk for the different organizational structures. ${ }^{11}$ According to the results in Panels A and C, financial holding companies are significantly more X-efficient than are M\&As or LICs, respectively. Panels B and C indicate that the ROE of FHCs also is statistically larger on average than that of FSCs but smaller than that of LICs. The latter finding is not consistent with the contention that FHCs gain advantages from their financial conglomeration. In addition, the results in Panel F show that the ROE of FSCs averages less than that of LICs. Finally, we find the highest underwriting risk for FSCs but the lowest among LICs. Overall, we find significant differences in X-efficiency performance, profitability, and risk taking among different forms of life insurance companies.

Table 3. Differences in Means of Dependent Variables by Organization Structure

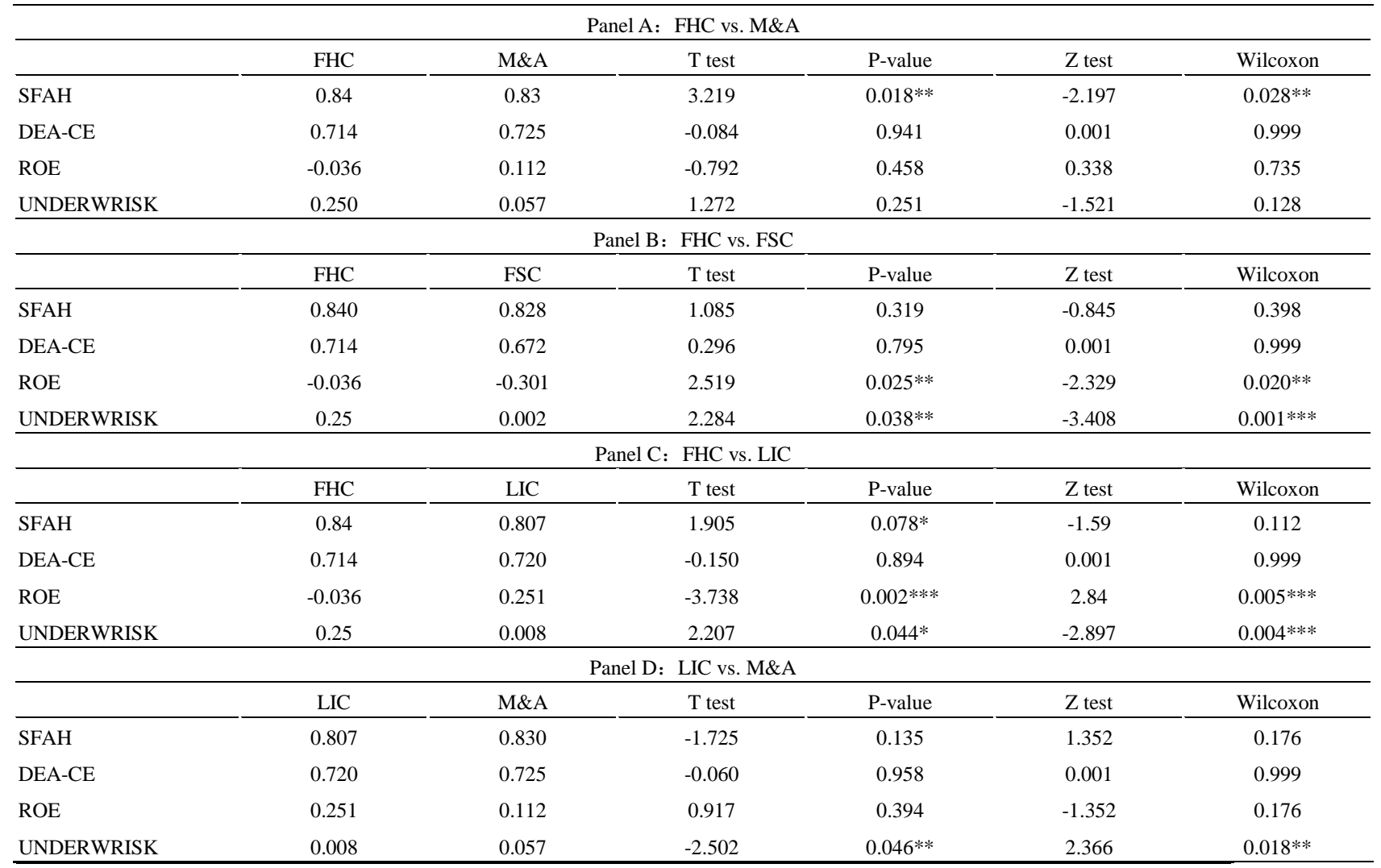

\begin{tabular}{|c|c|c|c|c|c|c|}
\hline & FSC & $\mathrm{M} \& \mathrm{~A}$ & T test & $\mathrm{P}$-value & $\mathrm{Z}$ test & Wilcoxon \\
\hline SFAH & 0.828 & 0.830 & 0.074 & 0.943 & 0.105 & 0.917 \\
\hline DEA-CE & 0.672 & 0.725 & 0.891 & 0.467 & -1.069 & 0.285 \\
\hline ROE & -0.301 & 0.112 & 1.22 & 0.268 & 1.352 & 0.176 \\
\hline UNDERWRISK & 0.002 & 0.057 & 2.502 & $0.046 * *$ & 2.366 & $0.018 * *$ \\
\hline \multicolumn{7}{|c|}{ Panel F: FSC vs. LIC } \\
\hline & FSC & LIC & $\mathrm{T}$ test & $\mathrm{P}$-value & $\mathrm{Z}$ test & Wilcoxon \\
\hline SFAH & 0.828 & 0.807 & 1.313 & 0.237 & 1.352 & 0.176 \\
\hline DEA-CE & 0.672 & 0.720 & -0.415 & 0.718 & -0.535 & 0.593 \\
\hline ROE & -0.301 & 0.251 & -8.799 & $0.000 * * *$ & 9.643 & $0.000^{* * *} *$ \\
\hline UNDERWRISK & 0.002 & 0.008 & -3.479 & $0.001 * * *$ & 3.932 & $0.000 * * *$ \\
\hline
\end{tabular}

11 We also provide results of the null hypothesis the means of the variables for the two distinct types of companies are equal. These tests include $\mathrm{T}$ test, $\mathrm{Z}$ test, and Wilcoxon. 
Note: This table summarizes the differences in the means of the dependent variables used in the regression analyses across various types of companies. FHC $=$ financial holding company; FSC $=$ foreign subsidiary company; LIC $=$ local independent company; $\mathrm{M} \& \mathrm{~A}=$ merger and acquisition company. SFAH = efficiency scores measured by the stochastic frontier approach; DEA-CE = efficiency scores measured by the DEA approach. $\mathrm{ROE}=$ return on equity. UNDERWRISK = risk of claim, measured by the coefficient of variation of three years claim. The data come from the Life Insurance Association of the Republic of China, 2000 to 2002. The null hypothesis states that the means of the variables will be equal for different types of companies.

*Statistically significant at the $10 \%$ level. ** Statistically significant at the 5\% level. *** Statistically significant at the $1 \%$ level.

Table 4 contains the descriptive statistics for the variables used in the regression analysis. We find that FHCs are the largest and FSCs the smallest in terms of total assets. Furthermore, the different forms of insurance companies focus on different lines of insurance. For example, LICs earn a higher proportion of individual life insurance premiums, whereas FSCs rely on a higher proportion of health and accident lines of business than do the other types of companies. Finally, M\&A companies are more specialized than are the other forms in terms of the lines of business Herfindahl index.

Table 4. Descriptive Statistics for Life Insurance Companies

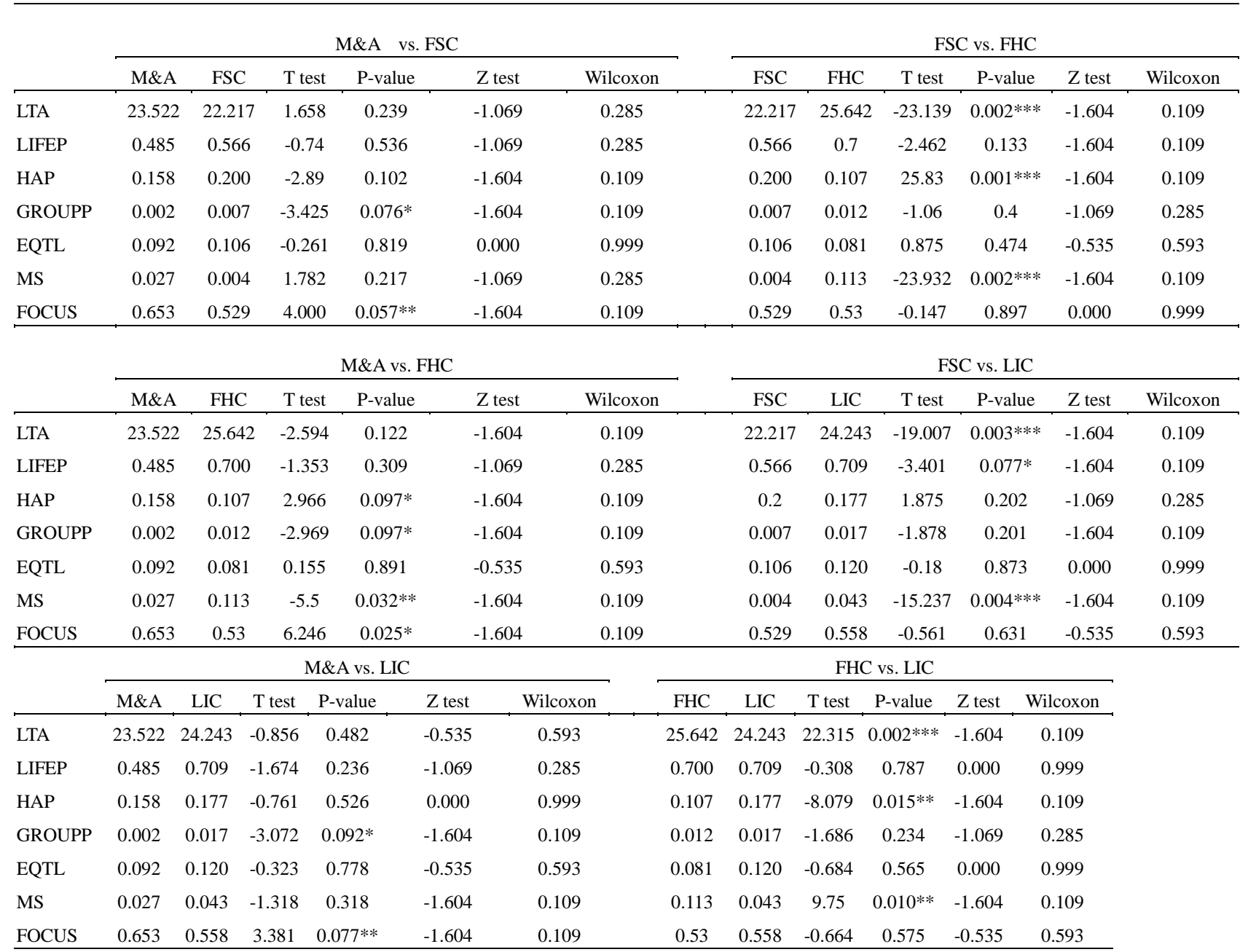

Note: This table presents the descriptive statistics for the independent variables used in the regression analysis. The samples include unbalanced panel data, 2000-2002. FHC $=$ financial holding company; FSC $=$ foreign subsidiary company; LIC = local independent company; M\&A = merger and acquisition company. LTA $=$ log of total assets. LIFEP $=$ life insurance premium share of total premium; $\mathrm{HAP}=$ health and accident insurance premium share of total premium; GROUPP $=$ group insurance premium share of total premium. $\mathrm{EQTL}=$ equity-liability ratio. $\mathrm{MS}=$ market share. $\mathrm{TA}=$ total assets. FOCUS $=$ line-of-business Herfindahl index $=\left(Y_{1}^{2}+Y_{2}^{2}+Y_{3}^{2}+. Y_{4}^{2}\right) /\left(Y_{1}+Y_{2}+Y_{3}+. Y_{4}\right)^{2} . \mathrm{Y}_{1}=$ ordinary 
life insurance premiums, $\mathrm{Y}_{2}=$ accident and health premiums, $\mathrm{Y}_{3}=$ group life insurance premiums, $\mathrm{Y}_{4}=$ investments. The total asset variable is expressed in millions of NTD.

*Statistically significant at the $10 \%$ level. ** Statistically significant at the $5 \%$ level. *** Statistically significant at the $1 \%$ level.

\section{Empirical Results}

In this section, we discuss the efficiency, profitability, and risk-taking regression results. Table 5 presents the results of regressions when the estimated efficiency is based on SFA; Table 6 contains the results when we use the DEA cost efficiency scores as an alternative efficiency measurement. For expositional ease, we focus primarily on the results in Table 5, then discuss how the DEA approach results in Table 6 differ.

Table 6 Seemingly Unrelated Regression Results (DEA Approach)

\begin{tabular}{|c|c|c|c|c|c|c|c|c|c|}
\hline Dependent Variables & & (1) DEA-CE & & & (2) ROE & & & UNDERWR & SK \\
\hline$\alpha_{i t}$ & $\begin{array}{c}0.302 \\
(0.029)^{* *}\end{array}$ & $\begin{array}{c}0.582 \\
(0.000)^{* * *}\end{array}$ & $\begin{array}{c}0.312 \\
(0.049)^{* *}\end{array}$ & $\begin{array}{c}-1.740 \\
(0.000)^{* * *}\end{array}$ & $\begin{array}{c}-1.613 \\
(0.000)^{* * *}\end{array}$ & $\begin{array}{c}-1.357 \\
(0.012)^{* *}\end{array}$ & $\begin{array}{c}12.278 \\
(0.000)^{* * *}\end{array}$ & $\begin{array}{c}9.645 \\
(0.000)^{* * *}\end{array}$ & $\begin{array}{c}8.644 \\
(0.002)^{* * * *}\end{array}$ \\
\hline FHC & $\begin{array}{l}-0.089 \\
(0.198)\end{array}$ & $\begin{array}{l}-0.937 \\
(0.175)\end{array}$ & $\begin{array}{l}-0.851 \\
(0.204)\end{array}$ & $\begin{array}{c}-0.476 \\
(0.002)^{* * *}\end{array}$ & $\begin{array}{c}-0.493 \\
(0.001)^{* * *}\end{array}$ & $\begin{array}{c}-0.493 \\
(0.001)^{* * *}\end{array}$ & $\begin{array}{c}0.863 \\
(0.453)\end{array}$ & $\begin{array}{c}0.947 \\
(0.395)\end{array}$ & $\begin{array}{c}0.999 \\
(0.369)\end{array}$ \\
\hline$M \& A$ & $\begin{array}{l}-0.026 \\
(0.792)\end{array}$ & $\begin{array}{l}-0.058 \\
(0.570)\end{array}$ & $\begin{array}{l}-0.110 \\
(0.266)\end{array}$ & $\begin{array}{c}0.053 \\
(0.814)\end{array}$ & $\begin{array}{l}-0.055 \\
(0.806)\end{array}$ & $\begin{array}{l}-0.618 \\
(0.978)\end{array}$ & $\begin{array}{c}5.414 \\
(0.011)^{* *}\end{array}$ & $\begin{array}{c}4.583 \\
(0.005)^{* * *}\end{array}$ & $\begin{array}{c}4.371 \\
(0.008)^{* * * *}\end{array}$ \\
\hline FSC & $\begin{array}{l}-0.041 \\
(0.682)\end{array}$ & $\begin{array}{l}-0.012 \\
(0.905)\end{array}$ & $\begin{array}{c}0.015 \\
(0.875)\end{array}$ & $\begin{array}{l}-0.061 \\
(0.784)\end{array}$ & $\begin{array}{l}-0.026 \\
(0.872)\end{array}$ & $\begin{array}{l}-0.050 \\
(0.820)\end{array}$ & $\begin{array}{c}5.368 \\
(0.001)^{* * *}\end{array}$ & $\begin{array}{c}5.712 \\
(0.000)^{* * *}\end{array}$ & $\begin{array}{c}5.843 \\
(0.000)^{* * * *}\end{array}$ \\
\hline FOCUS (\%) & $\begin{array}{c}0.338 \\
(0.000)^{* * *}\end{array}$ & - & $\begin{array}{c}0.510 \\
(0.000)^{* * *}\end{array}$ & $\begin{array}{l}-0.221 \\
(0.243)\end{array}$ & - & $\begin{array}{c}-0.407 \\
(0.089)^{*}\end{array}$ & $\begin{array}{c}-2.620 \\
(0.051)^{*}\end{array}$ & $\begin{array}{l}- \\
-\end{array}$ & $\begin{array}{c}2.160 \\
(0.204)\end{array}$ \\
\hline UNDERWRISK & - & $\begin{array}{l}- \\
-\end{array}$ & - & $\begin{array}{l}-0.010 \\
(0.146)\end{array}$ & $\begin{array}{l}-0.005 \\
(0.514)\end{array}$ & $\begin{array}{l}-0.456 \\
(0.515)\end{array}$ & - & - & - \\
\hline DEA-CE $(\%)$ & - & - & - & $\begin{array}{c}0.237 \\
(0.044)^{* *}\end{array}$ & $\begin{array}{c}0.315 \\
(0.251)\end{array}$ & $\begin{array}{c}0.171 \\
(0.149)\end{array}$ & - & - & - \\
\hline LTA & $\begin{array}{c}0.011 \\
(0.088)^{*}\end{array}$ & $\begin{array}{c}0.016 \\
(0.012)^{* *}\end{array}$ & $\begin{array}{c}0.015 \\
(0.018)^{* *}\end{array}$ & $\begin{array}{c}0.081 \\
(0.000)^{* *}\end{array}$ & $\begin{array}{c}0.085 \\
(0.000)^{* * *}\end{array}$ & $\begin{array}{c}0.083 \\
(0.000)^{* * *}\end{array}$ & $\begin{array}{c}-0.375 \\
(0.000)^{* * *}\end{array}$ & $\begin{array}{c}-3.044 \\
(0.004)^{* * *}\end{array}$ & $\begin{array}{c}-0.317 \\
(0.003)^{* * *}\end{array}$ \\
\hline $\operatorname{LIFEP}(\%)$ & - & $\begin{array}{c}-0.218 \\
(0.007)^{* * *}\end{array}$ & $\begin{array}{c}-0.335 \\
(0.000)^{* * *}\end{array}$ & - & $\begin{array}{c}-0.354 \\
(0.046)^{* *}\end{array}$ & $\begin{array}{l}-0.260 \\
(0.161)\end{array}$ & - & $\begin{array}{c}-2.246 \\
(0.082)^{*}\end{array}$ & $\begin{array}{c}-2.760 \\
(0.040)^{* *}\end{array}$ \\
\hline $\operatorname{HAP}(\%)$ & - & $\begin{array}{c}-0.326 \\
(0.003)^{* * *}\end{array}$ & $\begin{array}{c}0.017 \\
(0.892)\end{array}$ & - & $\begin{array}{c}-0.520 \\
(0.036)^{* *}\end{array}$ & $\begin{array}{c}-0.769 \\
(0.008)^{* * *}\end{array}$ & - & $\begin{array}{c}6.299 \\
(0.004)^{* * *}\end{array}$ & $\begin{array}{c}7.783 \\
(0.000)^{* * * *}\end{array}$ \\
\hline GROUPP (\%) & - & $\begin{array}{c}0.012 \\
(0.948)\end{array}$ & $\begin{array}{c}0.011 \\
(0.955)\end{array}$ & - & $\begin{array}{c}0.814 \\
(0.051)^{*}\end{array}$ & $\begin{array}{c}0.813 \\
(0.051)^{*}\end{array}$ & - & $\begin{array}{c}-8.682 \\
(0.005)^{* * *}\end{array}$ & $\begin{array}{c}-8.694 \\
(0.004)^{* * *} *\end{array}$ \\
\hline EQTL $(\%)$ & $\begin{array}{c}-0.069 \\
(0.001)^{*}\end{array}$ & $\begin{array}{c}-0.009 \\
(0.001)^{* * *}\end{array}$ & $\begin{array}{c}-0.011 \\
(0.000)^{* * *}\end{array}$ & $\begin{array}{c}0.001 \\
(0.870)\end{array}$ & $\begin{array}{l}-0.538 \\
(0.305)\end{array}$ & $\begin{array}{l}-0.004 \\
(0.492)\end{array}$ & $\begin{array}{c}-0.072 \\
(0.037)^{* *}\end{array}$ & $\begin{array}{c}-0.086 \\
(0.023)^{* *}\end{array}$ & $\begin{array}{c}-0.094 \\
(0.015)^{* *}\end{array}$ \\
\hline $\operatorname{MS}(\%)$ & -- & -- & -- & $\begin{array}{c}0.848 \\
(0.002)^{* * *}\end{array}$ & $\begin{array}{c}0.817 \\
(0.002)^{* * *} \\
\end{array}$ & $\begin{array}{c}0.915 \\
(0.000)^{* * *}\end{array}$ & $\begin{array}{c}-4.791 \\
(0.000)^{* * *}\end{array}$ & $\begin{array}{c}-4.982 \\
(0.000)^{* * *}\end{array}$ & $\begin{array}{c}-4.759 \\
(0.000)^{* * *}\end{array}$ \\
\hline LM Test & 229.62 & 269.29 & 202.44 & 73.13 & 55.34 & 57.01 & 163.01 & 99.44 & 96.69 \\
\hline$P$ value & $0.000 * * *$ & $0.000 * * *$ & $0.000 * * *$ & $0.000 * * *$ & $0.000 * * *$ & $0.000 * * *$ & $0.000 * * *$ & $0.000 * * *$ & $0.000 * * *$ \\
\hline Hausman Test & 35.47 & 20.56 & 19.32 & 12.02 & 18.00 & 24.62 & 18.66 & 18.81 & 19.88 \\
\hline$P$ value & $0.000 * * *$ & $0.008^{* *}$ & $0.023^{* *}$ & 0.150 & $0.055^{* * * *}$ & $0.010^{* * *}$ & $0.005^{* * *}$ & $0.016^{* *}$ & $0.019 * *$ \\
\hline Adj- $R^{2}$ & 0.073 & 0.055 & 0.110 & 0.164 & 0.156 & 0.186 & 0.144 & 0.196 & 0.195 \\
\hline
\end{tabular}

Numbers in parentheses are (P-value).

Note: This table presents regression results. The sample includes unbalanced panel data. DEA-CE = efficiency scores measured by DEA approach. ROE = return on equity. UNDERWRISK = risk of claim measured by the coefficient of variation of three years claim. $\mathrm{FHC}=$ dummy variable, equal to 1 if the insurer is a financial holding company, 0 otherwise. $\mathrm{M} \& \mathrm{~A}=$ dummy variable, equal to 1 if the insurer is a merger and acquisition company, 0 otherwise. FSC = dummy variable, equal to 1 if the insurer is a foreign subsidiary insurer, 0 otherwise. The omitted category is local independent life insurance companies. FOCUS $=$ line of business Herfindahl index. LTA $=\log$ of total assets. LIFEP = life insurance premium share of total premium; HAP = health and accident insurance premium share of total premium; GROUPP = group insurance premium share of total premium. EQTL = equity-liability ratio. MS = market share. 
*Statistically significant at the $10 \%$ level. ** Statistically significant at the $5 \%$ level. *** Statistically significant at the $1 \%$ level.

\subsection{Efficiency Regression Results}

We first discuss the link between organizational structure and X-efficiency. As noted, we include three variables to represent organizational structure-FHC, M\&A, and FSC. The local independent insurer is the omitted category. According Model (1) of Table 5, the coefficients for FHC are negative and significant in the X-efficiency equation, which implies that these companies, on average, underperform LICs on this measure. We can reject null hypothesis I that organizational structures have no impact on efficiency.

Table 5. Seemingly Unrelated Regression Results (SFAH Approach)

\begin{tabular}{|c|c|c|c|c|c|c|c|c|c|}
\hline \multirow{2}{*}{$\frac{\text { Dependent Variables }}{\alpha_{i t}}$} & \multicolumn{3}{|c|}{ (1) SFAH } & \multicolumn{3}{|c|}{ (2) ROE } & \multicolumn{3}{|c|}{ (3) UNDERWRISK } \\
\hline & 0.910 & 0.912 & 0.914 & -0.655 & -0.568 & -0.287 & 12.039 & 9.872 & 8.492 \\
\hline & $(0.000)^{* * *}$ & $(0.000)^{* * *}$ & $(0.000)^{* * *}$ & $(0.295)$ & $(0.355)$ & $(0.653)$ & $(0.000)^{* * *}$ & $(0.000)^{* * *}$ & $(0.002)^{* * *}$ \\
\hline \multirow[t]{2}{*}{ FHC } & -0.026 & -0.027 & -0.027 & -0.514 & -0.526 & -0.526 & 0.842 & 0.972 & 0.986 \\
\hline & $(0.081)^{*}$ & $(0.079)^{*}$ & $(0.078)^{*}$ & $(0.000)^{* * *}$ & $(0.001)^{* * *}$ & $(0.000)^{* * *}$ & $(0.464)$ & $(0.383)$ & $(0.375)$ \\
\hline \multirow[t]{2}{*}{$M \& A$} & 0.003 & 0.007 & 0.007 & 0.054 & -0.053 & -0.117 & 5.388 & 4.601 & 4.357 \\
\hline & $(0.877)$ & $(0.767)$ & $(0.753)$ & $(0.809)$ & $(0.813)$ & (0.958) & $(0.001)^{* * *}$ & $(0.005)^{* * *}$ & $(0.008)^{* * *}$ \\
\hline \multirow[t]{2}{*}{ FSC } & -0.028 & -0.030 & -0.030 & -0.099 & -0.061 & -0.755 & 5.385 & 5.737 & 5.832 \\
\hline & $(0.200)$ & $(0.176)$ & $(0.174)$ & $(0.658)$ & $(0.783)$ & $(0.732)$ & $(0.001)^{* * * *}$ & $(0.000)^{* * * *}$ & $(0.003)^{* * * *}$ \\
\hline \multirow[t]{2}{*}{ FOCUS (\%) } & 0.007 & - & -0.004 & -0.171 & - & -0.361 & -2.542 & - & 2.208 \\
\hline & $(0.706)$ & & $(0.852)$ & $(0.360)$ & & (0124) & $(0.057)^{*}$ & & (0.194) \\
\hline \multirow[t]{2}{*}{ UNDERWRISK } & -- & -- & -- & -0.826 & -0.004 & -0.004 & & & \\
\hline & - & - & - & $(0.224)$ & $(0.571)$ & $(0.607)$ & - & & \\
\hline SFAH(\%) & - & - & - & $\begin{array}{c}-0.996 \\
(0.053)^{*}\end{array}$ & $\begin{array}{c}-0.975 \\
(0.054)^{*}\end{array}$ & $\begin{array}{c}-1.002 \\
(0.047) * *\end{array}$ & - & - & - \\
\hline \multirow[t]{2}{*}{ LTA } & 0.000 & 0.000 & 0.000 & 0.079 & 0.084 & 0.082 & -0.365 & -0.315 & -0.311 \\
\hline & $(0.863)$ & $(0.965)$ & (0.958) & $(0.000)^{* *}$ & $(0.000)^{* * *}$ & $(0.000)^{* * *}$ & $(0.001)^{* * *}$ & $(0.003)^{* * *}$ & $(0.004)^{* * *}$ \\
\hline \multirow[t]{2}{*}{ LIFEP (\%) } & & 0.011 & 0.012 & & -0.382 & -0.306 & & -2.274 & -2.756 \\
\hline & - & $(0.525)$ & $(0.507)$ & - & $(0.029)^{* *}$ & $(0.092)^{*}$ & - & $(0.078)^{*}$ & $(0.040)^{* *}$ \\
\hline \multirow[t]{2}{*}{$\operatorname{HAP}(\%)$} & & -0.009 & -0.011 & & -0.558 & -0.789 & & 6.347 & 7.789 \\
\hline & - & $(0.724)$ & $(0.691)$ & - & $(0.023)^{* *}$ & $(0.006)^{* * *}$ & - & $(0.000)^{* * *}$ & $(0.000)^{* * *}$ \\
\hline \multirow[t]{2}{*}{ GROUPP (\%) } & & 0.018 & 0.018 & & 0.837 & 0.840 & & -8.689 & -8.691 \\
\hline & - & $(0.660)$ & $(0.660)$ & & $(0.045)^{* *}$ & $(0.043)^{* *}$ & & $(0.005)^{* * * *}$ & $(0.005)^{* * *}$ \\
\hline \multirow[t]{2}{*}{ EQTL (\%) } & 0.000 & 0.000 & 0.000 & -0.000 & -0.006 & -0.005 & -0.727 & -0.086 & -0.094 \\
\hline & $(0.665)$ & $(0.539)$ & $(0.525)$ & $(0.935)$ & $(0.222)$ & $(0.335)$ & $(0.037)^{* *}$ & $(0.023)^{* *}$ & $(0.014)^{* *}$ \\
\hline \multirow[t]{2}{*}{ MS (\%) } & -- & -- & -- & 1.029 & 0.953 & 1.062 & -5.111 & -4.626 & -4.956 \\
\hline & -- & -- & -- & $(0.000)^{* * *}$ & $(0.000)^{* * *}$ & $(0.000)^{* * *}$ & $(0.000)^{* * * *}$ & $(0.000)^{* * * *}$ & $(0.000)^{* * *}$ \\
\hline LM Test & 359.74 & 365.42 & 365.26 & 83.48 & 61.38 & 62.66 & 169.49 & 102.24 & 99.77 \\
\hline$P$ value & $0.000 * * *$ & $0.000^{* * *}$ & $0.000^{* * *}$ & $0.000^{* * *}$ & $0.000^{* * *}$ & $0.000^{* * *}$ & $0.000^{* * *}$ & $0.000^{* * *}$ & $0.000 * * *$ \\
\hline Hausman Test & 6.34 & 32.72 & 39.54 & 0.95 & 17.32 & 20.41 & 19.43 & 18.81 & 19.83 \\
\hline$P$ value & 0.274 & $0.000^{* * *}$ & $0.000 * * *$ & 0.204 & $0.068^{*}$ & $0.040^{* *}$ & $0.007 * * *$ & $0.027 * *$ & $0.031 * *$ \\
\hline Adj- $R^{2}$ & 0.005 & 0.010 & 0.010 & 0.153 & 0.375 & 0.180 & 0.133 & 0.185 & 0.185 \\
\hline
\end{tabular}

Numbers in parentheses are (P-value).

Note: This table presents regression results. The sample includes unbalanced panel data. SFAH = efficiency scores measured by the stochastic frontier approach. ROE = return on equity. UNDERWRISK = risk of claim measured by the coefficient of variation of three years claim. FHC $=$ dummy variable, equal to 1 if the insurer is a financial holding company, 0 otherwise. $\mathrm{M} \& \mathrm{~A}=$ dummy variable, equal to 1 if the insurer is a merger and acquisition company, 0 otherwise. FSC = dummy variable, equal to 1 if the insurer is a foreign subsidiary insurer, 0 otherwise. The omitted category is local independent life insurance companies. FOCUS $=$ line of business Herfindahl index. LTA $=\log$ of total assets. LIFEP = life insurance premium share of total premium; HAP = health and accident insurance premium share of total premium; GROUPP = group insurance premium share of total premium. EQTL = equity-liability ratio. $\mathrm{MS}=$ market share. 
*Statistically significant at the $10 \%$ level. ** Statistically significant at the $5 \%$ level. *** Statistically significant at the $1 \%$ level.

With regard to the relationship between business strategy and X-efficiency, we note that the coefficient for FOCUS is not significant in Table 5 but has a positive and statistically significant coefficient in the efficiency equations in Table 6 . Therefore, specialized life insurers appear more dominant than diversified life insurers in terms of their cost efficiency, and we may reject null hypothesis IV that there is no relation between business strategy and efficiency. This result is consistent with findings by Carr et al. (1999) and Cummins et al. (2003) in the U.S insurance industry.

In terms of the control variables, we find that the coefficient of LTA relates positively to efficiency in Table 6; companies improve their efficiency by increasing their size and scale of operations, in line with Berger's (1993) findings. The LIFEP and HAP coefficients in Table 6 are negative and significant, which implies that companies are less efficient when they underwrite more life and health insurance. We also find a significantly negative coefficient of EQTL in the efficiency regression in Table 6, consistent with our expectation of a positive relationship between financial leverage and efficiency.

Overall, our findings reject null hypotheses I and IV and suggest that organizational structures and business strategy have significant impacts on insurer efficiency.

\subsection{Profitability Regression Results}

Model (2) of Tables 5 and 6 pertains to the profitability regression. The FHC coefficients in both tables reject our null hypothesis II that different organizational structures have no impact on a firm's profitability, because FHCs appear less profitable than LICs. This finding is similar to the results provided by Nakatani (1984) for industrial firms in keiretsu groups; however, it contrasts with claims of efficiency gains through the provision of financial conglomeration to customers. We believe this result may occur because FHCs tend to pay larger claims or incur higher expenses than do other types of companies (see descriptive statistics in Table 2). Also, independent firms do not suffer the agency problem of cross-subsidization, which may reduce the profitability of insurance firms.

The result for our null hypothesis $\mathrm{V}$, which indicates no relation between business strategy and profitability, again suggests rejection. The coefficient of FOCUS is negative and statistically significant at the $10 \%$ level in Table 6 . Therefore, specialized insurers are less profitable than diversified insurers.

The coefficients of our efficiency measures are negative and statistically significant in Model (2) of Table 5 but significantly positive in Table 6. The difference in these results may emerge because the SFA approach is econometric and imposes distributional assumptions for the error terms, whereas DEA is a mathematical programming method that does not require this distributional assumption. Cummins and $\mathrm{Zi} \mathrm{(1998)} \mathrm{show} \mathrm{that} \mathrm{the} \mathrm{results} \mathrm{of} \mathrm{econometric} \mathrm{and}$ mathematical programming methods do not always converge; the selection of estimation method thus can have a significant impact on the conclusions of an efficiency study.

In addition, we find that the size coefficients (LTA) are positive and statistically significant, such that larger insurers are more profitable than small ones, in support of scale efficiency. The LIFEP and HAP coefficients are statistically negative, so companies earn less profit when they underwrite more individual life and/or health insurance policies. In contrast, the statistically positive GROUPP coefficients indicate that companies are more profitable when they issue more group insurance policies. Finally, we find that the coefficients of the market share ratios are significantly positive; a company with more market share is more profitable. This result is consistent with the prediction of a positive relation between market share and profitability by Berger and Humphrey (1997). In summary, our findings from the regression analysis suggest that profitability varies with different organizational structures and business strategies, in rejection of null hypotheses II and V.

\subsection{Risk-Taking Behavior Regression Results}

The regression results regarding risk-taking behavior, in Model (3) of Tables 5 and 6, enable us to reject null hypothesis III, which states that organizational structures have no impact on risk-taking behavior. The coefficients of M\&As and FSCs are positive and statistically significant; these organizations experience more underwriting risk than do LICs. Therefore, organizational structure has a significant impact on firms' risk-taking behaviors. In addition, the FOCUS coefficient in the risk-taking regression model is negative and statistically significant at the $10 \%$ level in Tables 5 and 6 , in rejection of the null hypothesis VI that there is no relationship between business strategy and risk taking.

With regard to the control variables, we find that the coefficients of LTA (log of total assets) in both tables are negative and statistically significant, implying that small insurers, on average, take more risk than larger ones. The coefficients of LIFEP and GROUPP are statistically negative, so insurance companies that issue more life and/or group insurance lines also likely have lower risk, but the coefficient of HAP is positive and statistically significant at the $1 \%$ level, so the more health and accident insurance an insurer issues, the higher is its underwriting risk. The EQTL exhibits 
significantly negative coefficients, which imply that insurers with greater financial leverage adopt a higher level of underwriting risk. The market share coefficients also are negative and significant, such that insurance firms with higher market share have lower risk. Overall, the results of the risk-taking models show that underwriting risk varies significantly depending on organizational structures and business strategies, and we reject our null hypotheses III and VI.

The empirical evidence is summarized below. The results show that financial holding companies have lower profitability than local independent companies. Merger and acquisition companies and foreign subsidiary companies take more risk than other types of firms. In addition, the organizational structure has impact on the efficiency. Foreign subsidiary companies' $\mathrm{X}$ efficiency score are inferior to other type of insurance company. Finally, we find that business strategies have impact on the efficiency or risk-taking behavior. Thus, the insurance company with higher concentration on health and accident insurance would have higher underwriting risk, lower efficiency and less profit. Other main findings are summarized as follows. Large insurance companies perform better in terms of efficiency and profitability than smaller companies. We also find more cost efficient companies have higher profitability.

\section{Conclusions}

This paper examines whether different organizational structures and business strategies have a significant impact on firm efficiency, profitability and the risk-taking behavior of companies in the Taiwanese life insurance industry using seemingly unrelated regression equations. The main findings reject null hypotheses that there is no impact of organizational structure and business strategy on the firm efficiency, profitability and the risk-taking behaviors. Specific results are summarized as below.

We first provide the results of the impact of organizational structure on the firm profitability, efficiency, and risk-taking behavior. We demonstrate that financial holding companies are less profitable and less efficient than are local independent companies. One possible reason is that the input prices of financial holding companies are higher than those of local independent companies. The merger and acquisition companies and foreign subsidiary companies insurance companies, on average, underwrite more risky policies than local independent insurance companies. Second, we find that business strategies have significant impacts on the efficiency, profitability, and risk taking of insurers. Specialized life insurers tend to have lower underwriting risk and are more cost efficient, but they are also less profitable than diversified life insurers. Overall, the implication of our results is that, first, a more competitive environment should be encouraged in the Taiwanese insurance industry; inefficient insurers need to undertake greater efforts to improve. Second, life insurance companies undergoing merger and acquisition event must choose their business strategy carefully to position themselves appropriately in the marketplace.

Despite these key insights, which extend prior research into the effects of organizational structure and business strategy, we call for additional work in this research context. In particular, given the relationships we find in this analysis, investigations of the relationships between organizational structure and risk and return trade-offs in other financial service industries, such as banking, seem warranted.

\section{References}

Aigner, D. J., Lovell, C. A., \& Schmdit, P. (1977). Formulation and estimation of stochastic frontier production function models, Journal of Econometrics, 6, 1-37.

Amihud, Y., \& Lev, B. (1981) Risk reduction as a managerial motive for conglomerate mergers, The Bell Journal of Economics, 12, 605-617.

Baranoff, E. G., \& Sager, T. W. (2002) The relations among asset risk, product risk, and capital in the life insurance industry, Journal of Banking and Finance, 26, 1181-1197.

Baranoff, E. G., \& Sager, T. W. (2003) The relations among organizational and distribution forms and capital and asset risk structures in the life insurance industry, Journal of Risk and Insurance, 70, 375-400.

Battese, G. E., \& Coelli, T. J. (1992) Frontier production functions, technical efficiency and panel data: with application to paddy farmers in India, Journal of Productivity Analysis, 3, 153-169.

Battese, G. E., \& Coelli, T. J. (1995) A model for technical inefficiency effects in a stochastic frontier production function for panel data, Empirical Economics, 20, 325-332.

Bauer, P. W., Berger, A. N., \& Humphrey, D. B. (1993) Efficiency and productivity growth in U.S. banking, In H.O. Fried, C.A.K. Lovell, and S.S. Schmidt (Ed.), The measurement of productive efficiency: Techniques and applications, New York: Oxford University Press, 386-413.

Bauer, P. W., \& Hancock, D. (1993) The efficiency of the Federal Reserve in providing check processing services, Journal of Banking and Finance, 17, 287-311. 
Berger, A. N. (1993) Distribution free estimates of efficiency of the U.S. banking industry and tests of the standard distributional assumptions, Journal of Productivity Analysis, 4, 261-292.

Berger, A. N., Cummins, J. D. Weiss, M. A., \& Zi, H. (2000). Conglomeration versus strategic focus: evidence from the insurance industry, Journal of Financial Intermediation, 9, 323-362.

Berger, A. N., \& Humphrey, D. B. (1997). Efficiency of financial institutions: international survey and directions for future research, European Journal of Operational Research, 98, 175-212.

Berger, A. N., \& Mester, L. J. (1997). Inside the black box: what explains differences in the efficiencies of financial institutions. Journal of Banking Finance, 21, 895-947.

Berger, P. G., \& Ofek, E. (1995). Diversification's Effect on Firm Value, Journal of Financial Economics, 37, 39-65.

Berle, A., \& Means, G. (1932). The Modern Corporation and Private Property, New York: Macmillan.

Blair, R. D., Jackson, J. R., \& Vogel, R. J. (1975). Economies of scale in the administration of health insurance, Review of Economics and Statistics, 185-89.

Brewer, E. B. (1989). Relationship between bank holding company risk and nonbank activity, Journal of Economics and Business, 41, 337-353.

Brealey, R. A., Myers, S. C., \& Allen, F. (2003). Principles of Corporate Finance, $8^{\text {th }}$ ed. New York: McGraw-Hill, 877-879.

Breusch, T., \& Pagan, P. (1979). A simple test for heteroscedasticity and random coefficient variation, Econometrica, 47, 1287-1294.

Calomiris, C. W. (1998). Universal banking 'American style', Journal of Institutional and Theoretical Economics, 154, 44-60.

Carr, R. M., Cummins, J. D., \& Regan, L. (1999). Efficiency and competitiveness in the U.S. life insurance industry: corporate, product, and distribution strategies, In: J. D. Cummins and A. M. Santomero, (Ed.), Changes in the Life Insurance Industry: Efficiency, Technology and Risk Management. Norwell, MA: Kluwer Academic Publishers, 117-158.

Cebenoyan, A. S., Cooperman, E. S. Register, C. A., \& Hudgins, S. C. (1993). The relative efficiency of stock versus mutual S and Ls: A stochastic cost frontier approach, Journal of Financial Services Research, 7(2), 151-170.

Coase, R. H. (1960). The problem of social cost, Journal of Law and Economics, 3, 1-44.

Comment, R., \& Jarrell, G. A. (1995). Corporate focus and stock returns, Journal of Financial Economics, $37,67-87$.

Cummins, J. D., \& Nini, G. P. (2002). Optimal capital utilization by financial firms: evidence from the property-liability insurance industry, Journal of Financial Services Research, 21, 15-53.

Cummins, J. D., \& Rubio-Misas, M. (2006). Deregulation, consolidation, and efficiency: evidence from the Spanish insurance industry, Journal of Money, Credit, and Banking, 38(2), 323-55.

Cummins, J. D., \& Sommer, D. W. (1996). Capital and risk in property-liability insurance market, Journal of Banking and Finance, 20, 1069-1092.

Cummins, J. D., Tennyson, S., \& Weiss, M. A. (1999). Consolidation and efficiency in the U.S. life insurance industry, Journal of Banking and Finance, 23, 325-357.

Cummins, J. D., \& Weiss, M. A. (2000). Analyzing firm performance in the insurance industry using frontier efficiency and productivity method, In: G. Dionne (Ed.), Handbook of Insurance. New York: Kluwer Academic Publishers.

Cummins, J. D., Weiss, M. A., \& Zi, H. (1999). Organizational form and efficiency: an analysis of stock and mutual property-liability insurers, Management Science, 45, 1254-1269.

Cummins, J. D., Weiss, M. A., \& Zi, H. (2003). Economies of scope in financial services: a DEA bootstrapping analysis of the US insurance industry, Unpublished working paper, The Wharton School, University of Pennsylvania.

Cummins, J. D., \& Zi, H. (1998). Comparison of frontier efficiency methods: an application to the U.S. life insurance industry, Journal of Productivity Analysis, 10, 131-152.

Cummins, J. D., \& Xie, X. Y. (2008). Mergers and acquisitions in the US property-liability insurance industry: Productivity and efficiency effects,Journal of Banking \& Finance, 32, 30-55.

Doherty, N. (1991). The design of insurance contracts when liability rules are unstable, Journal of Risk and Insurance, $58,227-45$

Doherty, N., \& Dionne, G. (1993). Insurance with undiversifiable risk: contract structure \& organization form of 
insurance firms, Journal of Risk and Uncertainty, 6, 187-203.

Elango, B., Ma, Y., \& Pope, N. (2008). An investigation into the diversification-performance relationship in the U.S. property-liability insurance industry, Journal of Risk and Insurance, 75, 567-591.

Esho, N., Kofman, P., \& Sharpe, I. G. (2005). Diversification, fee income, and credit union risk, Journal of Financial Services Research, 27(3), 259-281.

Fama, E. F., \& Jensen, M. C. (1983a). Separation of ownership and control, Journal of Law and Economics, 26, 301-325.

Fama, E. F., \& Jensen, M. C. (1983b). Agency problems and residual claims, Journal of Law and Economics, 26, 327-349.

Gale, B. T., \& Branch, B. S. (1982). Concentration versus market share: which determines performance and why does it matter, Antitrust Bulletin, 27, 83-106.

Gallo, J. G., Apilado, V. P., \& Kolari, J. W. (1996). Commercial bank mutual fund activities: Implications for bank risk and profitability, Journal of Banking and Finance, 20, 1775-1791.

Gardner, L. A., \& Grace, M. F. (1993). X-efficiency in the US life insurance industry, Journal of Banking and Finance, 17, 497-510.

Grabowski, R., Rangan, N., \& Rezvanian, R. (1993). Organizational forms in banking: An empirical investigation of cost efficiency, Journal of Banking and Finance, 17(2-3), 531-538.

Grace, M. F., Timme, S. G. (1992). An examination of cost economies in the United States life insurance industry, Journal of Risk \& Insurance, 59, 72-103.

Hao, C. J., \& Chou, L. Y. (2005). The estimation of efficiency for life insurance industry: the case in Taiwan, Journal of Asian Economics, 16, 847-860.

Hassan, M. K., Karels, G. V., \& Peterson, M. O. (1994). Deposit insurance, market discipline and off-balance sheet banking risk of large U.S. commercial banks, Journal of Banking and Finance, 18, 575-593.

Hausman, J. (1978). Specification tests in econometrics, Econometrica, 46, 1251-1271.

Herring, R. J., \& Santomero, A. M. (1990). The corporate structure of financial conglomerates, Journal of Financial Services Research, 4, 471-497.

Iannotta, G., Nocera, G., \& Sironi, A. (2007). Ownership structure, risk and performance in the European banking industry, Journal of Banking and Finance, 31, 2127-2149.

Jeng, V., \& Lai, G. C. (2005). Ownership structure, agency costs and efficiency: analysis of keiretsu and independent insurers in Japanese non-life insurance industry, Journal of Risk and Insurance, 72(1), 105-158.

Jensen, M. C. (1986). Agency costs of free cash flow, corporate finance and takeovers, American Economic Review, 76, 323-339.

Jensen, M. C., \& W. H. Meckling (1976). Theory of the firm: managerial behavior, agency costs and ownership structure, Journal of Financial Economics, 3, 297-326.

Jones, G. R., \& Hill, C. W. L. (1988). Transaction Cost Analysis of Strategy-Structure Choice, Strategic Management Journal, 9, pp, 159-172.

Kochhar, R. (1996). Explaining firm capital structure: the role of agency theory vs. transaction cost economics, Strategic Management Journal, 17, 713-728.

Lai, G. C., \& Limpaphayom, P. (2003). Organizational structure and performance: evidence from the nonlife insurance industry in Japan, Journal of Risk and Insurance, 70(4), 735-757.

Lamm-Tennant, J., \& Starks, L. (1993). Stock versus mutual ownership structures: the risk implications, Journal of Business, 66(1), 29-46.

Liebenberg, A. P., \& Sommer, D.W. (2008). Effects of corporate diversification: evidence from the property-liability insurance industry, Journal of Risk and Insurance, 75, 893-919.

Liebeskind, J., \& Opler, T. C. (1993). The causes of corporate refocusing, Unpublished working paper, Southern Methodist University, Dallas, TX.

Martin, J. D., \& Sayrak, A. (2003). Corporate diversification and shareholder value: a survey of recent literature, Journal of Corporate Finance, 9(1), 37-5.

Mayers, D., \& Smith, C. W. (1981). Contractual provisions, organizational structure, and conflict control in insurance 
markets, Journal of Business, 54, 407-434.

Mayers, D., \& Smith, C. W. (1986). Ownership structure and control: the mutualization of stock life insurance companies, Journal of Financial Economics, 16, 73-98.

Mayers, D., \& Smith, C. W. (1988). Ownership structure across lines of property casualty insurance,' Journal of Law and Economics, 31, 351-378.

Mayers, D., \& Smith, Jr.C. W. (1990). On the corporate demand for insurance: evidence from the reinsurance market, Journal of Business, 63, 19-40.

Mayers, D., \& Smith, C. W. (1992). Executive compensation in the life insurance industry, Journal of Business, 65, 51-74.

Meador, J. W., Ryan, H. E., \& Schellhorn, C. D. (2000). Product Focus Versus Diversification: Estimates of X-Efficiency for the U.S. Life Insurance Industry, in: P. T. Harker and S. A. Zenios, eds., Performance of Financial Institutions (New York: Cambridge University Press)..

Mester, L. J. (1993). Efficiency in the savings and loan industry, Journal of Banking and Finance, 17(2-3), 267-286.

Nakatani, I. (1984). The economic role of corporate financial grouping, In: M. Aoki, (Ed.)., Economic Analysis of the Japanese Firm. North-Holland, Amsterdam.

Rai, A. (1996). Cost efficiency of international insurance industry, Journal of Financial Services Research, 10, 213313.

Servaes, H., (1996)., The Value of Diversification During the Conglomerate Merger Wave, Journal of Finance, 51, 1201-1225.

Smirlock, M., Gilligan, T., \& Marshall, W. (1986). Tobin's q and the structure-performance relationship: reply, American Economic Review, 74, 1211-1213.

Smith, B. D., \& Stutzer, M. (1990). Adverse selection, aggregate uncertainty, and the role for mutual insurance contracts, Journal of Business, 63, 493-510.

Stevens, J. L. (1990). Tobin's q and the structure-performance relationship: comment, American Economic Review, 80, 618-623.

Teece, D. J. (1980). Economies of scope and the scope of the enterprise, Journal of Economic Behavior and Organization, 1, 223-247.

Weiss, M. A. (1986). Analysis of Productivity at the Firm Level: An Application to Life Insurers, Journal of Risk and Insurance, 53, 49-84.

Wells, B. P., L. A. Cox, \& K. M. Gaver (1995). Free cash flow in the life insurance industry, Journal of Risk and Insurance, 62(1), 50-66.

Williamson, O. (1963). Managerial discretion and business behavior, American Economic Review, 53, 1032-1057.

Williamson, O. E. (1970). Corporate Control and Business Behavior: An Inquiry Into the Effects of Organizational Form on Enterprise Behavior. Englewood Cliffs, NJ: Prentice Hall. 
Appendix: Table A.1. Variable Definitions

Variable

Definition

Unit

Panel A: Translog Cost Function

\begin{tabular}{lll} 
TC & Total cost is total operating costs, which should vary with input & NT. 1 million \\
$Y_{1}$ & The ordinarv life insurance premium. & NT. 1 million \\
$Y_{2}$ & The accident and health premium. & NT. 1 million \\
$Y_{3}$ & The group life insurance premium. & NT. 1 million \\
$Y_{4}$ & The group accident and health premium. & NT. 1 million \\
$P_{i w}$ & Prices of labor & NT. one dollar \\
$P_{k}$ & Prices of phvsical capital & NT. one dollar \\
$P_{B}$ & Prices of claim & NT. one dollar \\
\hline
\end{tabular}

Panel B: Regression Analvsis

Dependent Variable

SFAH

Relative efficiency scores. This score is estimated by stochastic \% frontier. approach.

DEA-CE

Relative efficiency scores. This score is estimated by DEA

$\%$ approach.

ROE

Net income over equity

$\%$

UNDERWRISK

The risk of claim, measured by the coefficient of variation of three $\%$ years claim.

Independent Variable

FHC

Dummy variable, which equals 1 if an insurer is a financial

holding company, 0 otherwise.

$\mathrm{M} \& \mathrm{~A}$

Dummy variable, which equals 1 if insurer is a merger and acquisition company, 0 otherwise.

FSC

Dummy variable, which equals 1 if an insurer is a foreign

subsidiary insurer, 0 otherwise.

FOCUS

LTA

Line of business Herfindahl index. Focus $=\frac{Y_{1}^{2}+Y_{2}^{2}+Y_{3}^{2}+Y_{4}^{2}}{\left(Y_{1}+Y_{2}+Y_{3}+Y_{4}\right)^{2}}$

Log of total asset.

LIFEP (\%).

The life insurance premium share of total premiums.

HAP $(\%)$.

The health and accident insurance premium share of total premiums.

GROUPP (\%)

The group insurance premium share of total premiums.

EQTL $(\%)$

Equity to liability. 
MS

Each firm's market share calculated as the total premium of \% insurance firm divided by total premium of life insurance industry,

\section{(c) EY}

This work is licensed under a Creative Commons Attribution 3.0 License. 